\title{
Article \\ Development of a Sulfate Resistance Performance Test for Concrete by Tensile Strength Measurements: Determination of Test Conditions
}

\author{
Johannes Haufe ${ }^{1,2, *(\mathbb{D})}$, Anya Vollpracht ${ }^{2}\left(\mathbb{D}\right.$ and Thomas Matschei ${ }^{2}$ \\ 1 ZERTplus Überwachungsgesellschaft mbH, Mühlenweg 11, 06749 Bitterfeld-Wolfen, Germany \\ 2 Institute of Building Materials Research, RWTH Aachen University, Schinkelstraße 3, 52062 Aachen, \\ Germany; vollpracht@ibac.rwth-aachen.de (A.V.); matschei@ibac.rwth-aachen.de (T.M.) \\ * Correspondence: j.haufe@zertplus.de
}

\section{check for}

updates

Citation: Haufe, J.; Vollpracht, A.; Matschei, T. Development of a Sulfate Resistance Performance Test for Concrete by Tensile Strength

Measurements: Determination of Test Conditions. Crystals 2021, 11, 1001. https://doi.org/10.3390/ cryst11081001

\section{Academic Editors: Yang Yu,}

Weiqiang Wang, Rafael Shehu and Beatrice Pomaro

Received: 9 July 2021

Accepted: 19 August 2021

Published: 22 August 2021

Publisher's Note: MDPI stays neutral with regard to jurisdictional claims in published maps and institutional affiliations.

Copyright: (c) 2021 by the authors. Licensee MDPI, Basel, Switzerland. This article is an open access article distributed under the terms and conditions of the Creative Commons Attribution (CC BY) license (https:// creativecommons.org/licenses/by/ $4.0 /)$.

\begin{abstract}
Assessing the sulfate resistance of concrete is essential for the use of concrete in sulfate rich environments. A multitude of test methods exists worldwide, showing the relevance of the problem and the difficulty to find a suitable test setup. Testing the relative tensile strength of ASTM C307 concrete briquette specimens after exposure to a sulfate solution is a new direct method to assess the degree of deterioration. The aim of this study is to develop a new performance test, which considers both the chemical and physical resistance of a specific concrete mix against sulfate attack. In the experimental investigations, the binder type, storage temperature, type and concentration of sulfate solution, and concrete composition were varied, and the remaining tensile strength evaluated to define the test parameters. To gain significantly distinguishable data within nine months of storage, the use of sodium sulfate solution with $6000 \mathrm{mg} \mathrm{SO}_{4}{ }^{2-} / \mathrm{L}$ at $5{ }^{\circ} \mathrm{C}$ is proposed.
\end{abstract}

Keywords: sulfate attack; concrete; tensile strength; X-ray diffraction

\section{Introduction}

Understanding the reaction mechanism during sulfate attack on concrete has been an important research objective for decades [1]. Although there is a general agreement on which binders are considered sulfate resistant and which are susceptible to the attack, the classification between these extremes is difficult. Additionally, the use of artificial lab test conditions often generates artifacts that are lacking in practical relevance [2,3]. Therefore, no satisfactory test method could be established until now [4].

The hydration of cement results in the formation of strength developing C-S-H, portlandite $\left(\mathrm{Ca}(\mathrm{OH})_{2}\right)$, and ettringite $\left(\mathrm{Ca}_{6}(\mathrm{Al}, \mathrm{Fe})_{2}\left(\mathrm{SO}_{4}\right)_{3}(\mathrm{OH})_{12} \cdot 26 \mathrm{H}_{2} \mathrm{O}\right)$. After the consumption of sulfates during the formation of ettringite, remaining aluminate reacts with ettringite to AFm-phases such as monosulfate $\left(3 \mathrm{CaO} \cdot(\mathrm{Al}, \mathrm{Fe})_{2} \mathrm{O}_{3} \cdot \mathrm{CaSO}_{4} \cdot \mathrm{nH}_{2} \mathrm{O}\right)$ [5]. The ingress of additional sulfate can result in the formation of new ettringite from these AFm-phases, and possibly lead to the precipitation of gypsum. Both reactions are accompanied by an increase in volume, resulting in macroscopic expansion, cracking, and deterioration of the concrete.

The sulfate resistance of concrete is always a combination of the chemical resistance of the binder and the physical resistance against the ingress of the attacking liquid $[6,7]$. This presents a major difficulty to correctly consider these two factors independently in a lab test. To test the resistance of cement and concrete against the deterioration by sulfate attack, a multitude of different methods exists worldwide. These tests are conducted on cement paste, mortar, and concrete specimens in complete immersion, half-immersion, or under cyclic exposition to sulfate solutions of a great variety of concentrations at different temperatures. In this context, the expansion of a specimen caused by the precipitation of sulfate containing minerals, like ettringite and gypsum, is usually assessed as a measure 
for the sulfate resistance [8-16]. The characterization of changes of the dynamic elastic modulus to detect internal microstructural damage is also a common method applied in the literature [15,17-20]. Rarely, the remaining flexural [21-25] or tensile strengths [26-28] are tested.

However, cracking and a related loss of strength and surface scaling due to the formation of ettringite and gypsum represent the main concern in relation to concrete structures in the field exposed to sulfate attack. In addition, at low temperatures, the presence of a carbonate source, e.g., due to added ground limestone or the ingress of $\mathrm{CO}_{2}$, a precipitation of thaumasite, may also result in a severe loss of strength [29].

In a previous study, we proposed a new approach to test the sulfate resistance of concrete using the tensile strength as a benchmark for the deterioration of concrete [30]. It was shown that briquette specimens according to ASTM C307-03 are especially suitable for this approach, since they require a reduced effort for testing compared to concrete prisms or cylinders. The results also showed that the extent of strength loss is dependent on the binder used to produce the concrete and on the storage conditions, e.g., the concentration of the sulfate solution.

Based on these promising results, a parameter study on the impact of relevant influencing parameters, such as storage temperature as well as type and concentration of sulfate solution, on the time-dependent evolution of tensile strength of concrete briquette specimens was conducted for a selection of cementitious binders and different concrete compositions. The presented results conclude with the proposition of optimal test conditions and a novel performance test procedure to evaluate the sulfate resistance of concrete.

\section{Materials and Methods}

\subsection{Materials}

Two Portland cements (CEM I $42.5 \mathrm{~N}$ and CEM I $42.5 \mathrm{~N}-\mathrm{SR} 3$ ), a Portland-composite cement (CEM II/B-S 42.5 N) and a blast furnace slag cement (CEM III/A $42.5 \mathrm{~N}$ ), as well as a hard coal fly ash (FA) were used in this study. The chemical composition of the materials was determined according to EN 196-2 by X-ray fluorescence, the chloride content by titration with silver nitrate solution, and the $\mathrm{SO}_{3}$ content by gravimetric analysis. The results are shown in Table 1. To determine the mineralogical composition shown in Table 2, a PANalitycal X'Pert Pro X-ray diffractometer (XRD) was used. Diffractograms were measured in a range between 7 and $55^{\circ} 2 \theta$ for $60 \mathrm{~min}$. The machine was operated at $40 \mathrm{kV}$ and $40 \mathrm{~mA}$. The amorphous content was evaluated by using rutile as an internal standard at a replacement level of $20 \mathrm{wt} \%$.

Table 1. Chemical composition of the cements and the fly ash.

\begin{tabular}{|c|c|c|c|c|c|}
\hline Component & CEM I $42.5 \mathrm{~N}$ & CEM I 42.5 N-SR3 & CEM II/B-S $42.5 \mathrm{~N}$ & CEM III/A $42.5 \mathrm{~N}$ & Fly Ash \\
\hline $\mathrm{CaO}$ & 64.7 & 62.8 & 55.5 & 49.8 & 3.2 \\
\hline $\mathrm{SiO}_{2}$ & 21.5 & 19.8 & 25.6 & 30.1 & 50.1 \\
\hline $\mathrm{Al}_{2} \mathrm{O}_{3}$ & 4.10 & 4.00 & 5.59 & 7.40 & 25.80 \\
\hline $\mathrm{Fe}_{2} \mathrm{O}_{3}$ & 2.71 & 6.55 & 1.83 & 1.17 & 7.29 \\
\hline $\mathrm{MgO}$ & 0.87 & 1.38 & 2.58 & 4.36 & 1.64 \\
\hline $\mathrm{K}_{2} \mathrm{O}$ & 0.62 & 1.01 & 0.63 & 0.58 & 2.03 \\
\hline $\mathrm{Na}_{2} \mathrm{O}$ & 0.34 & 0.14 & 0.39 & 0.37 & 0.91 \\
\hline $\mathrm{TiO}_{2}$ & 0.18 & 0.14 & 0.33 & 0.49 & 0.93 \\
\hline $\mathrm{Cl}^{-}$ & 0.056 & 0.054 & 0.028 & 0.061 & $<0.001$ \\
\hline $\mathrm{SO}_{3}$ & 2.76 & 2.56 & 2.81 & 3.13 & 0.65 \\
\hline LOI & 2.39 & 1.82 & 0.41 & -0.96 & 4.72 \\
\hline
\end{tabular}

\subsection{Concrete Composition}

Quartz gravel and sand from the river Rhine were used as aggregate for concrete production. A maximum grain size of $8 \mathrm{~mm}$ was utilized due to the smallest width of the briquette molds being $25.4 \mathrm{~mm}$. Quartz powder was used as filler. For concrete with a 
$\mathrm{w} / \mathrm{c}_{\mathrm{eq}}$ ratio of 0.45 , a grain size distribution according to a modified Andreasen model was utilized [31]. Concrete with $\mathrm{w} / \mathrm{c}_{\mathrm{eq}}=0.50$ was produced with a $\mathrm{C} 8$ grading curve according to DIN 1045-2.

Table 2. Mineralogical composition of the cements and the fly ash.

\begin{tabular}{|c|c|c|c|c|c|}
\hline Component & CEM I $42.5 \mathrm{~N}$ & CEM I 42.5 N-SR3 & CEM II/B-S $42.5 \mathrm{~N}$ & CEM III/A $42.5 \mathrm{~N}$ & Fly Ash \\
\hline Alite & 57.6 & 53.8 & 33.5 & 18.6 & - \\
\hline Belite & 13.0 & 9.6 & 6.1 & 4.1 & - \\
\hline $\mathrm{C}_{3} \mathrm{~A}$ & 7.4 & 3.0 & 5.0 & 2.7 & - \\
\hline Ferrite & 6.3 & 19.9 & 2.9 & 2.1 & - \\
\hline Gypsum & 0.9 & - & - & - & 0.1 \\
\hline Hemihydrate & 2.0 & 0.7 & 1.1 & 0.4 & 0.3 \\
\hline Anhydrite & 2.0 & 5.4 & 3.8 & 4.5 & - \\
\hline Calcite & $5.7 *$ & 5.1 & 0.1 & 0.2 & 0.8 \\
\hline Periclase & - & 0.5 & 0.2 & - & 0.2 \\
\hline Quartz & 1.1 & 0.6 & 0.2 & 0.1 & 4.8 \\
\hline Arcanite & 1.7 & 0.7 & 0.1 & - & - \\
\hline Ca-Langbeinite & 0.9 & 0.6 & 0.8 & 0.5 & - \\
\hline Lime & - & - & - & - & 0.1 \\
\hline Portlandite & 1.4 & - & 0.4 & 0.2 & - \\
\hline Mullite & - & - & - & - & 13.2 \\
\hline Hematite & - & - & - & - & 0.6 \\
\hline Magnetite & - & - & - & - & 0.9 \\
\hline Amorphous & - & - & 45.6 & 66.7 & 78.8 \\
\hline
\end{tabular}

* Value verified by chemical analysis.

The composition of the different concrete mixtures used in this study is given in Table 3. A PCE superplasticizer was used to achieve an equal flow of 180 to $220 \mathrm{~mm}$ in accordance with EN 1015-3 (Haegerman flow table). The air void content was tested according to EN 1015-7. For each mixture, 24 concrete specimens according to ASTM C307 (cf. Figure 1) as well as 12 standard prisms $\left(40 \times 40 \times 160 \mathrm{~mm}^{3}\right.$, EN 196-1) were casted and stored at $20^{\circ} \mathrm{C}$ and $90 \%$ relative humidity for $24 \mathrm{~h}$ before demolding. Afterwards the specimens were cured in saturated $\mathrm{Ca}(\mathrm{OH})_{2}$-solution at $20^{\circ} \mathrm{C}$ until an age of 28 days.

Table 3. Composition of the concrete mixtures (assumed air content: $2 \mathrm{vol} \%$ ).

\begin{tabular}{|c|c|c|c|c|c|c|c|c|}
\hline Component & M1 ${ }^{(2)}$ & M2 ${ }^{(2)}$ & M3 ${ }^{(2)}$ & M4 ${ }^{(3)}$ & M5 ${ }^{(3)}$ & M6 ${ }^{(3)}$ & M7 ${ }^{(2)}$ & M8 ${ }^{(3)}$ \\
\hline $\begin{array}{l}\text { Cement in } \\
\mathrm{kg} / \mathrm{m}^{3}\end{array}$ & 320 & 360 & 400 & 270 & 285 & 300 & 360 & 285 \\
\hline $\begin{array}{l}\text { Fly ash in } \\
\mathrm{kg} / \mathrm{m}^{3}\end{array}$ & - & - & - & 90 & 94 & 100 & - & 94 \\
\hline $\begin{array}{l}\text { Water in } \\
\mathrm{kg} / \mathrm{m}^{3}\end{array}$ & 144 & 162 & 180 & 138 & 145 & 153 & 180 & 162 \\
\hline $\mathrm{w} / \mathrm{c}_{\mathrm{eq}}(1)$ & \multicolumn{6}{|c|}{0.45} & \multicolumn{2}{|c|}{0.50} \\
\hline $\begin{array}{l}\text { Quartz } \\
\text { filler in } \\
\mathrm{kg} / \mathrm{m}^{3}\end{array}$ & 458 & 408 & 360 & 354 & 323 & 292 & 253 & 249 \\
\hline $\begin{array}{l}\text { Aggregate } \\
\text { in } \mathrm{kg} / \mathrm{m}^{3}\end{array}$ & 1473 & 1441 & 1767 & 1527 & 1519 & 1511 & 1548 & 1550 \\
\hline $\begin{array}{l}\text { Grading } \\
\text { curve }\end{array}$ & \multicolumn{6}{|c|}{$\begin{array}{c}\text { mod. Andreasen, } n=0.25 \\
\mathrm{D}=8 \mathrm{~mm}, \mathrm{~d}=1 \mu \mathrm{m}\end{array}$} & \multicolumn{2}{|c|}{ C8 (DIN 1045-2) } \\
\hline
\end{tabular}

${ }^{(1)} \mathrm{w} / \mathrm{c}_{\mathrm{eq}}=\mathrm{w} /(\mathrm{c}+\mathrm{k} \cdot \mathrm{f})$ with $\mathrm{k}=0.4, \mathrm{f} \ldots$ fly ash content ${ }^{(2)}$ concrete with CEM I, CEM I-SR3, CEM II/B-S and CEM III/A ${ }^{(3)}$ concrete with CEM I + fly ash. 

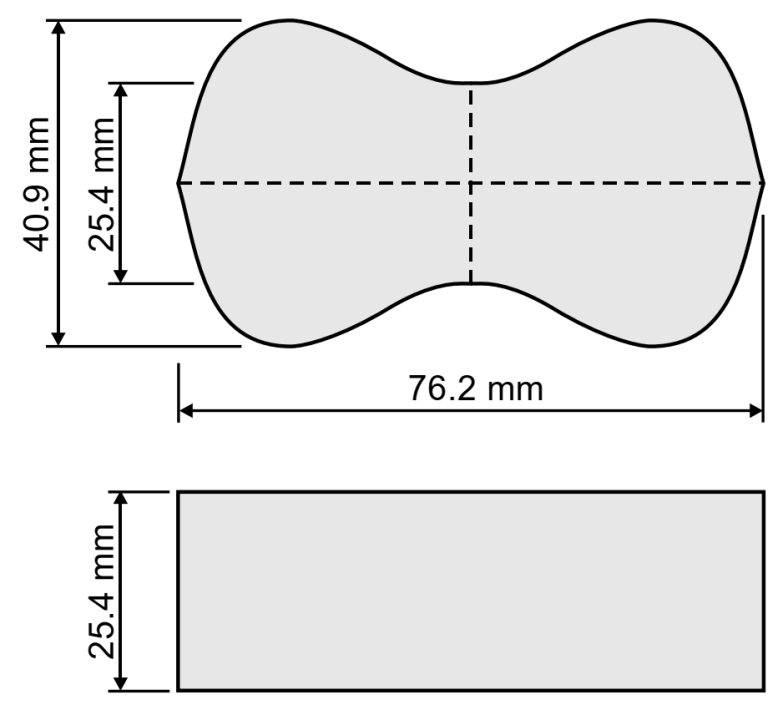

Figure 1. Briquette specimen according to ASTM C307.

After curing the specimens were stored in their respective storage solutions (solution to surface ratio $\approx 50 \mathrm{~L} / \mathrm{m}^{2}$ ) until testing. The sulfate solutions were renewed every 7 days until 28 days of storage and every 14 days subsequently.

\subsection{Design of Experiments}

A variety of influencing parameters on the sulfate resistance of concrete was evaluated to optimize the testing procedure. The sulfate resistance test shall be used as a performance test, meaning that it is intended to assess both the chemical and the physical resistance of a specific concrete mix. It is not intended to be used as a binder test (with a given $\mathrm{w} / \mathrm{c}$ ratio and a standard mix design). The concept is based on the conviction that, for practical application, it is irrelevant whether good sulfate resistance is achieved by a low chemical reactivity of the binder or by excellent physical properties, which prevent the ingress of sulfate into the concrete. The most important test parameters that need to be defined are the sulfate storage conditions (storage temperature, concentration of the sulfate solution) and the testing time. An overview on the examined test parameters can be seen in Table 4 . The parameter study was conducted on different selected binder types and contents were varied as well. The equivalent water to cement ratio was kept constant at $\mathrm{w} / \mathrm{c}_{\mathrm{eq}}=0.45$.

Table 4. Examined independent variables.

\begin{tabular}{cc}
\hline Independent Variable & Variation \\
\hline Temperature & $5{ }^{\circ} \mathrm{C}, 12^{\circ} \mathrm{C}, 20^{\circ} \mathrm{C}$ \\
Concentration of the sulfate solution & $3000 \mathrm{mg} \mathrm{SO}_{4}{ }^{2-} / \mathrm{L}, 6000 \mathrm{mg} \mathrm{SO}{ }^{2-} / \mathrm{L}$ \\
cement content & $320 \mathrm{~kg} / \mathrm{m}^{3}, 360 \mathrm{~kg} / \mathrm{m}^{3}, 400 \mathrm{~kg} / \mathrm{m}^{3}$ \\
cement + fly ash content & $(270+90) \mathrm{kg} / \mathrm{m}^{3},(285+94) \mathrm{kg} / \mathrm{m}^{3},(300+100) \mathrm{kg} / \mathrm{m}^{3}$ \\
\hline
\end{tabular}

Due to the number of parameters to be evaluated, a factorial design of experiment (DoE) was chosen to reduce lab work time. The parameters temperature, concentration, cation, and binder content were included in the approach, which accumulates to a full factorial design of 36 series for each type of binder. The software Minitab 18 was utilized to optimize the experimental program for a total of 20 series for each binder. The resulting combinations are shown in Table 5. 
Table 5. Factorial design of experiments.

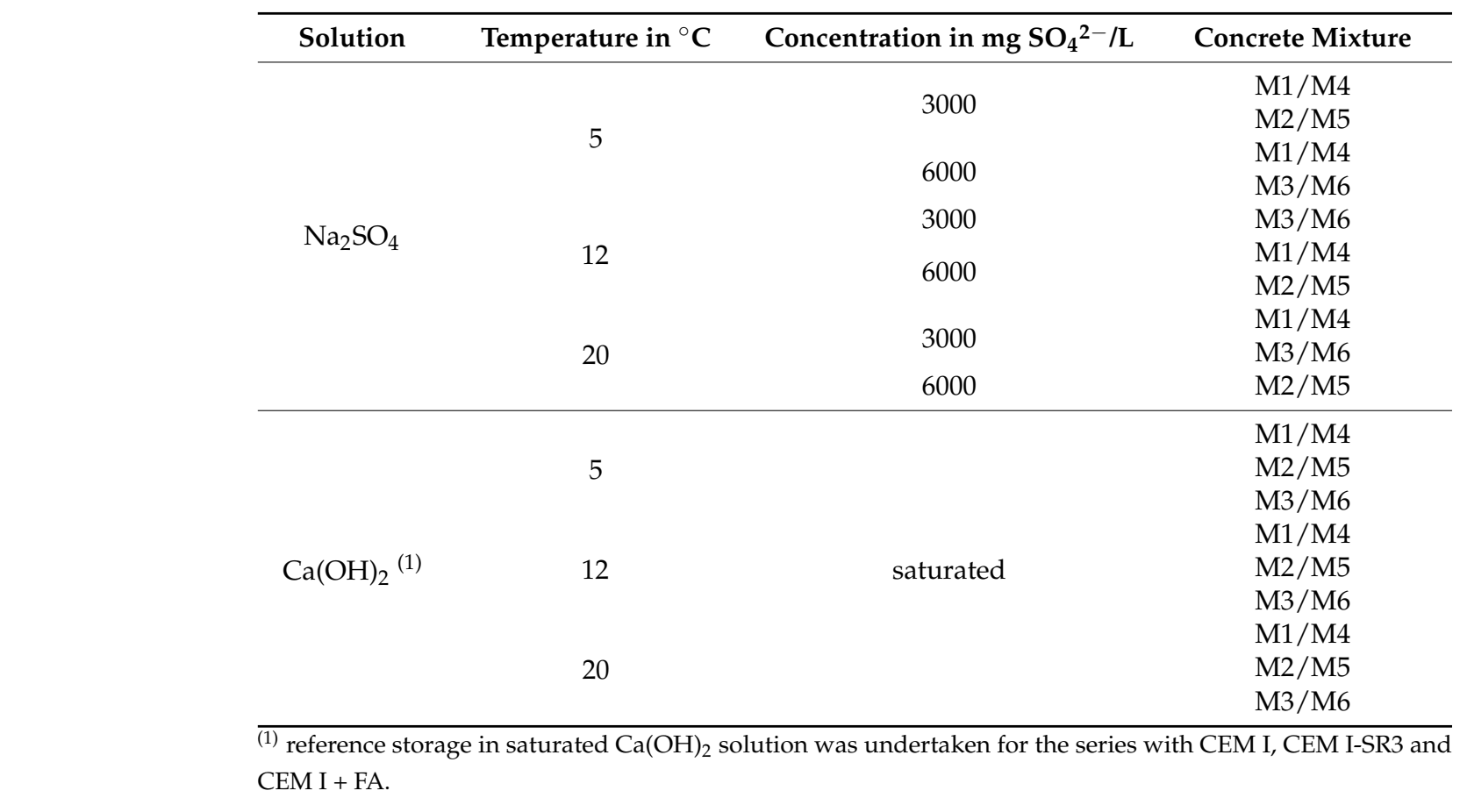

The intended testing procedure was optimized to obtain results within a reasonable time frame. Therefore, testing was initially undertaken until a storage time of six months at 56,119 , and 182 days of storage. Testing after nine months (273 days) of storage was added later in the study, while omitting the measurements after 56 days.

The remaining relative tensile strength after storage in sulfate solution was chosen as a benchmark for the sulfate resistance of concrete specimens. Additionally, the flexural strength of concrete standard prisms was examined to estimate whether the remaining relative flexural strength would perform similarly and could provide an alternative option.

\subsection{Data Analysis}

To evaluate the parametric study, multiple regression analyses were performed using the software Minitab 18. Regression models were calculated for the relative flexural strength and the relative tensile strength. As predetermined by the utilized DoE, the storage temperature, sulfate concentration, and binder content were considered as independent variables. Additionally, the fresh concrete density was included as independent variable to account for the influence of the production and casting of the concrete samples. Equation (1) shows the general approach that was chosen to calculate the regression models.

$f(T, b, c, \rho)=a_{1} \cdot T+a_{2} \cdot b+a_{3} \cdot c+a_{4} \cdot \rho+a_{5} \cdot T 2+a_{6} \cdot b 2+a_{7} \cdot \rho 2+a_{8} \cdot T \cdot b+a_{9} \cdot T \cdot c+a_{10} \cdot T \cdot \rho+a_{11}$
$\cdot b \cdot c+a_{12} \cdot b \cdot \rho+a_{13} \cdot c \cdot \rho$

where

- $\mathrm{T}$ is the temperature in ${ }^{\circ} \mathrm{C}$,

- $\quad \mathrm{b}$ is the binder content in $\mathrm{kg} / \mathrm{m}^{3}$,

- $\quad \mathrm{c}$ is the sulfate concentration in $\mathrm{mg} \mathrm{SO}_{4}{ }^{2-} / \mathrm{L}$,

- $\rho$ is the fresh concrete density in $\mathrm{g} / \mathrm{cm}^{3}$, and

- $\mathrm{a}_{\mathrm{i}}$ are the coefficients.

Significant variables and interactions were included stepwise in the regression model by forward selection. The contribution of the independent variables and interactions to the regression model was calculated by ANOVA (analysis of variance) for models with a coefficient of determination $\mathrm{R}^{2}$ above 0.50 . 
Significant differences between means of independent sets of data were verified by two-sample $t$-tests $(p=0.05)$. These calculations were carried out using Origin(Pro) 2019b.

\subsection{Methods}

\subsubsection{Strength Testing}

The mass of the briquette and prism specimen was measured after $56,119,182$, and 273 days of storage in the solutions. As reference the weight of the samples after 28 days curing was used.

The tensile strength of the briquette specimen was determined according to ASTM C307 using a universal testing machine Zwick ZMART.Pro with a $10 \mathrm{kN}$ load cell. The machine was operated path-controlled with a speed of $5 \mathrm{~mm} / \mathrm{min}$. To measure the flexural strength a testing machine, Form + Test with a $10 \mathrm{kN}$ load cell was used. The machine was operated in accordance with EN 196-1.

\subsubsection{Microstructural Analysis}

After 182 days of storage, the mineralogical zonation due to sulfate ingress was determined by means of X-ray diffraction. For the profiles, remaining halves of concrete prisms obtained after flexural strength testing (concrete prepared with $\mathrm{w} / \mathrm{c}_{\mathrm{eq}}=0.50$ stored at $5{ }^{\circ} \mathrm{C}$ in sodium sulfate solutions with $6000 \mathrm{mg} \mathrm{SO}_{4}{ }^{2-} / \mathrm{L}$ ) were used. The specimens were dried via solution exchange in isopropanol for $24 \mathrm{~h}$, followed by drying at $40^{\circ} \mathrm{C}$ for $72 \mathrm{~h}$. Later, the samples were ground in steps of $0.5 \mathrm{~mm}$ until a depth of $5 \mathrm{~mm}$. The temperature at the surface of the samples during the grinding process was kept below $40{ }^{\circ} \mathrm{C}$ to avoid dehydration of ettringite and gypsum. At each step, the powder was collected, ground to a grain size below $63 \mu \mathrm{m}$, and analyzed with an X-ray powder diffractometer Panalytical $X^{\prime}$ Pert Pro with an $X^{\prime}$ Celerator detector in a range of 5 to $55^{\circ} 2 \theta$ with a step size of $0.0167^{\circ} 2 \theta$ for a measurement time of six hours per sample. The results were analyzed qualitatively, followed by quantification using the Rietveld method. Due to the expected small amount of amorphous phase in the concrete samples, no internal or external standard was used [32].

The same powder samples used for XRD analysis were examined for their total $\mathrm{SO}_{3}$ content by carbon/sulfur analysis using an Eltra CS-2000.

Scanning electron microscopy (SEM) was performed on fractured samples of selected specimens after storage for 182 days using field emission SEMs JEOL JSM-7000F and Zeiss GeminiSEM 300. On polished sections, energy-dispersive X-ray (EDX) mappings of areas of $1.69 \cdot 1.32 \mathrm{~mm}^{2}$ were produced. The samples were previously embedded in epoxy resin, ground on a Buehler EcoMet 300 gradually with silicon carbide until a grit size of 4000, and subsequently polished with $3 \mu \mathrm{m}$ diamond spray. Each measurement took about $13 \mathrm{~h}$ and a grid of $1024 \cdot 800$ EDX spots was collected. The collected data were evaluated as a sum of $3 \cdot 3$ pixels to achieve better quantitative results. The aggregated EDX spectrum was quantified for aluminum, calcium, iron, potassium, sodium, magnesium, sulfur, and silicon to a total of $100 \mathrm{wt} \%$.

\section{Results}

The presented results of this study are divided into three main sections. At first, feasible test conditions to evaluate the deterioration of concrete specimen after sulfate storage by strength measurements had to be determined and assessed. Afterwards, the influence of the independent variables (temperature, concentration, binder content, fresh concrete density) on the dependent variables (here mainly rel. strength) was examined and conclusions for a proposed testing method drawn. These results constitute the main outcome of the study and are provided in Supplementary Materials.

Finally, results of microstructural analyses are presented to provide further information on the state of the concrete specimens after storage at the proposed storage conditions. 


\subsection{Determination of a Suitable Reference to Evaluate Strength Data}

In a first approach, the sulfate resistance was assessed by measuring the evolution of relative tensile strength of the sulfate immersed samples compared to samples stored in saturated $\mathrm{Ca}(\mathrm{OH})_{2}$ solution at 5,12 and $20^{\circ} \mathrm{C}$ as reference. However, this approach led to unsatisfactory and inconclusive results, because the scatter of the resulting relative tensile strength was high (cf. Figure $2 b$ ) and predominantly influenced by the varying density of the specific concrete sample (cf. Supplementary Materials). Therefore, the initial 28-day strength of the series stored in portlandite solution was considered as a constant reference value. This approach led to a steadier development of the curves, because the scatter of the strength testing of the reference samples was excluded. Consequently, the differences in tensile strength loss due to the storage conditions (cf. Figure 2c) could be distinguished. However, the ongoing hydration of the samples resulted in a higher strength of the specimens stored in sulfate solution compared to the 28-day strength. This effect causes relative strength values above 1 , which is usually not associated with damage. Hence, a maturity function was utilized to predict the strength at the respective testing time based on the 28-day strength of the samples stored in portlandite solution (cf. Figure 2d).
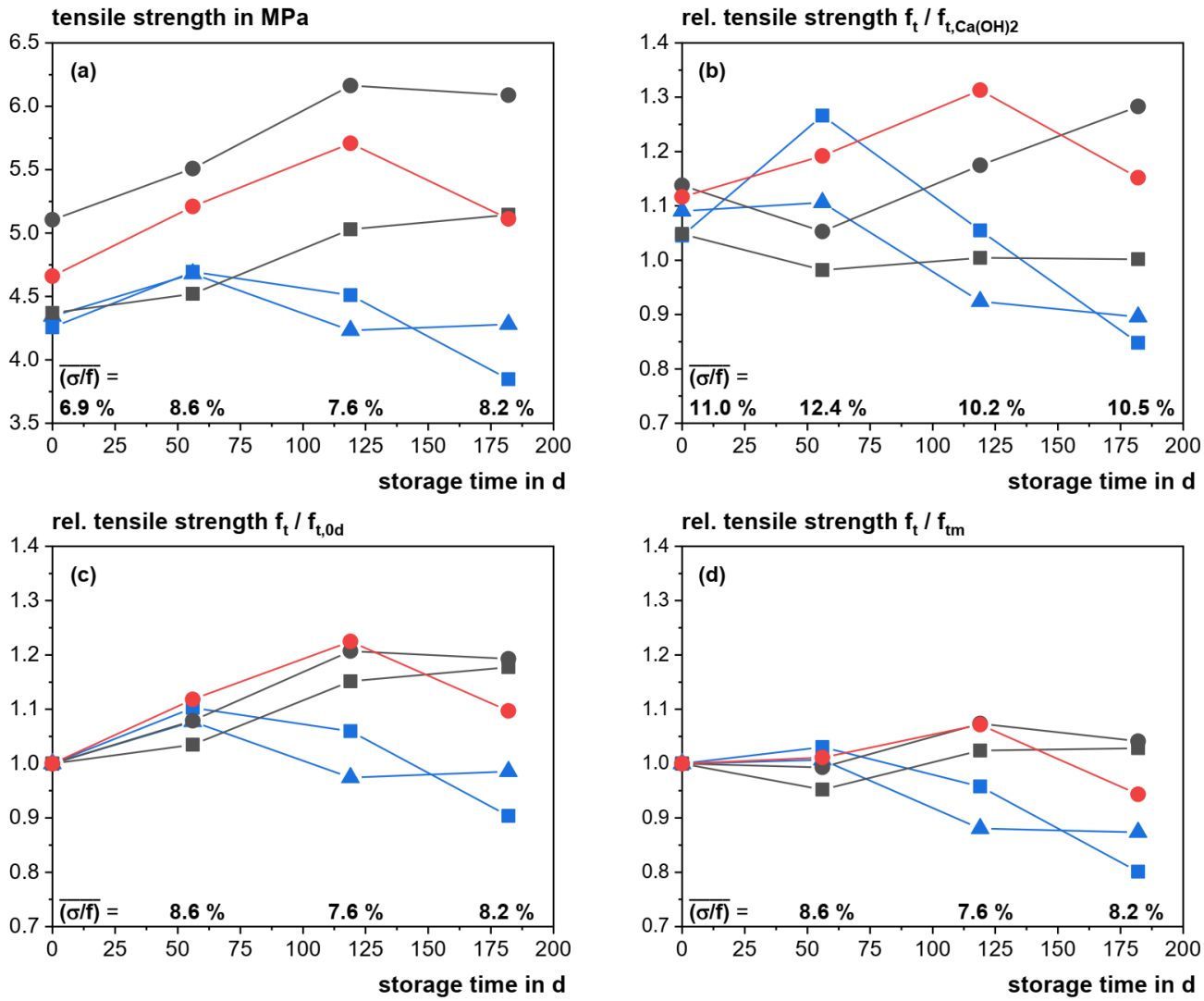

$-320 \mathrm{~kg} / \mathrm{m}^{3}, 5^{\circ} \mathrm{C}-400 \mathrm{~kg} / \mathrm{m}^{3}, 5^{\circ} \mathrm{C}-\square-320 \mathrm{~kg} / \mathrm{m}^{3}, 12{ }^{\circ} \mathrm{C}-0-360 \mathrm{~kg} / \mathrm{m}^{3}, 12{ }^{\circ} \mathrm{C}-0-360 \mathrm{~kg} / \mathrm{m}^{3}, 20{ }^{\circ} \mathrm{C}$

Figure 2. Exemplary results of concrete with CEM I $42.5 \mathrm{~N}$ and w/c $=0.45$ stored in $\mathrm{Na}_{2} \mathrm{SO}_{4}$ solution at $6000 \mathrm{mg} \mathrm{SO}_{4}{ }^{2-} / \mathrm{L}$, (a) tensile strength, $(\mathbf{b})$ relative tensile strength with $\mathrm{Ca}(\mathrm{OH})_{2}$-storage as a reference, $(\mathbf{c})$ relative tensile strength with $28 \mathrm{~d}$ strength as a reference (called $\mathrm{f}_{\mathrm{t}, 0 \mathrm{~d}}$ for $0 \mathrm{~d}$ of sulfate storage) and (d) relative tensile strength with the reference strength calculated with the maturity function.

The maturity function used in this work is adapted from the fib Model code [33] and has been altered, as suggested in the work of Vollpracht et al. [34], to account for the influence of SCMs on the strength development of concrete. It must be noted that the original method was developed to predict compressive strength. Nevertheless, our 
experimental results prove the suitability of the method for tensile strength data as shown below.

The tensile strength of concrete is calculated analogue to compressive strength from the strength at 28 days using Equation (2):

$$
\mathrm{f}_{\mathrm{tm}}(\mathrm{t})=\beta_{\mathrm{tc}}(\mathrm{t}) \cdot \mathrm{f}_{\mathrm{tm}, 28 \mathrm{~d}} \text { with } \beta_{\mathrm{tc}}(\mathrm{t})=\mathrm{e}^{\mathrm{s} \cdot\left(1-\sqrt{\frac{28 \mathrm{~d}}{\mathrm{t}}}\right)}
$$

where

- $\mathrm{f}_{\mathrm{tm}}(\mathrm{t})$ is the mean tensile strength in MPa at an age $\mathrm{t}$ in days,

- $\mathrm{f}_{\mathrm{tm}, 28 \mathrm{~d}}$ is the average tensile strength in MPa at an age of 28 days,

- $\beta_{t c}(t)$ is a function to describe the strength development with time,

- $t$ is the concrete age in days,

- $\mathrm{s}$ is a coefficient, which depends on the strength class of the cement, the water/binder ratio and the SCM content.

The s-value has been improved by Vollpracht et al. to account not just for the cement type, but also the content of SCM and the water/binder ratio as follows:

$$
\mathrm{s}=\mathrm{c}_{1} \cdot \frac{\mathrm{w}}{\mathrm{b}}+\mathrm{c}_{2} \cdot \frac{\mathrm{scm}}{\mathrm{b}}
$$

where

- $\mathrm{w} / \mathrm{b}$ is the free water to binder ratio,

- $\mathrm{scm} / \mathrm{b}$ is the mass proportion of SCM (fly ash and/or GGBS) in the binder,

- $c_{1}, c_{2}$ are coefficients depending on the strength class of the cement.

For cements with the strength class $32.5 \mathrm{~N}, 32.5 \mathrm{R}$ and $42.5 \mathrm{~N}$ coefficients $\mathrm{c}_{1}=0.528$ and $c_{2}=0.527$ have been determined, for cements $42.5 \mathrm{R}, 52.5 \mathrm{~N}$ and $52.5 \mathrm{R}$ the coefficients were calculated to $c_{1}=0.481$ and $c_{2}=0.441$ [34]. To account for the blast furnace slag present in the CEM II/B-S and CEM III/A examined in this study, the glass content measured by $\mathrm{XRD}$ was taken as an approximation of the SCM content in Equation (3).

To account for the influence of different storage temperatures of the concrete, the real concrete age $t$ (cf. Equation (3)) is replaced by a temperature-adjusted concrete age $t_{T}$ following the fib model code's maturity function as follows:

$$
\mathrm{t}_{\mathrm{T}}=\sum_{\mathrm{i}=1}^{\mathrm{n}} \Delta \mathrm{t}_{\mathrm{i}} \mathrm{e}^{\left[13.65-\frac{4000}{273+\mathrm{T}_{\alpha}\left(\Delta \mathrm{t}_{\mathrm{i}}\right)}\right]}
$$

where

- $\mathrm{t}_{\mathrm{T}}$ is the temperature-adjusted concrete age in days,

- $\Delta t_{\mathrm{i}}$ is the number of days where a temperature T $\alpha$ prevails in days,

- $\mathrm{T}_{\alpha}\left(\Delta \mathrm{t}_{\mathrm{i}}\right)$ is the temperature of concrete during time interval $\Delta \mathrm{t}_{\mathrm{i}}$ in ${ }^{\circ} \mathrm{C}$.

To verify the suitability of this approach for the tensile strength data in this work, the relative tensile strength after storage of concrete specimen in saturated $\mathrm{Ca}(\mathrm{OH})_{2}$ solution in relation to the tensile strength predicted by the maturity method was calculated. The tensile strengths of 27 series of concrete specimen (nine series with CEM I $42.5 \mathrm{~N}$, nine series with CEM I 42.5 N-SR3, nine series for CEM I 42.5 N + FA) were tested after 56, 119, and 182 days of storage. Figure 3 shows the results of these calculations. 
rel. tensile strength $\mathrm{f}_{\mathrm{t}} / \mathrm{f}_{\mathrm{tm}}$

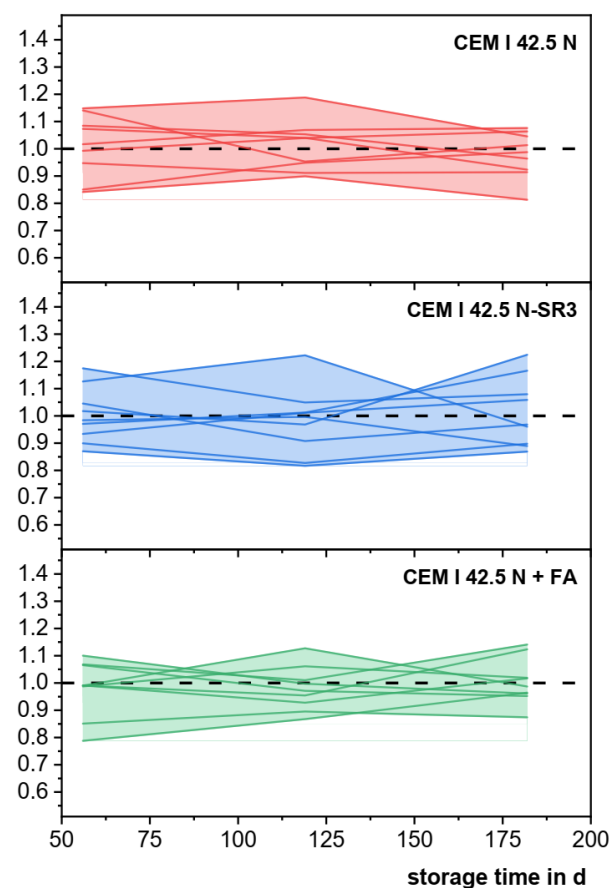

Figure 3. Relative tensile strength (ref.: maturity function) after storage in saturated $\mathrm{Ca}(\mathrm{OH})_{2}$ solution.

The relative tensile strength varies between 0.8 and 1.2. Normality tests were performed for each testing age as well as for the total set of 81 measurements (cf. Figure 4). All distributions follow a normality function and are centered on an average relative strength of $(0.99 \ldots 1.00)$ with a standard deviation of 0.10 . For comparison, the coefficient of variation of tensile strength testing itself was on average $7.61 \%$ in this work. It can be concluded that the approach of using the modified maturity function to predict the tensile strength of undamaged reference samples seems justified.

counts

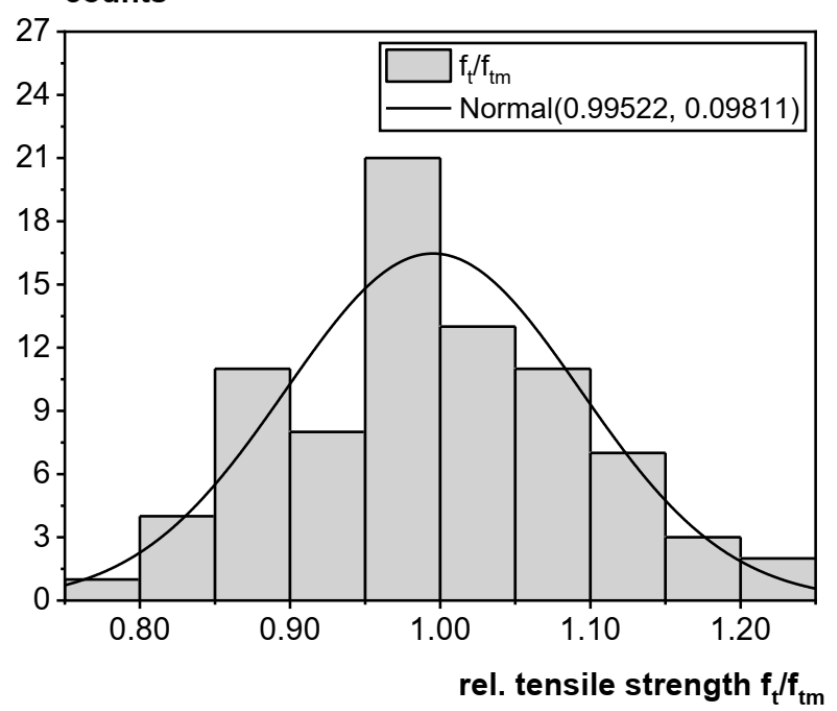

Figure 4. Histogram of the relative tensile strength (ref.: maturity function) and associated Gauss distribution for samples after storage in saturated $\mathrm{Ca}(\mathrm{OH})_{2}$ solution (series with CEM I $42.5 \mathrm{~N}, \mathrm{CEM}$ I $42.5 \mathrm{~N}-S R 3$ and CEM I $42.5 \mathrm{~N}+$ FA). 


\subsection{Strength Development}

Preliminary tests with magnesium sulfate solution mostly resulted in the formation of a brucite layer on the surface of the samples (determined by XRD and SEM). Since this attack mechanism is not representative for the cases found in Germany, the results are not discussed here. In order to provide results for the research community, we included the data in the Supplementary Materials.

\subsubsection{Flexural Strength}

Table 6 shows the quality of the models achieved for relative flexural strength of concrete with $\mathrm{w} / \mathrm{c}=0.45$ after a storage time of 182 days in sodium sulfate solution. The statistical models for the relative flexural strength are generally of low quality as reflected in the values of $R^{2}$, with an exception for the series with CEM I and fly ash. To prevent misinterpretation of the poor dependencies, the contributions of influencing variables on the respective models were not determined.

Table 6. Coefficient of variation $\mathrm{R}^{2}$ and contribution of independent variables/interactions for regression models of the relative flexural strength $\left(\mathrm{f}_{\mathrm{f}} / \mathrm{f}_{\mathrm{fm}}\right)$ of concrete with $\mathrm{w} / \mathrm{c}=0.45$ after 182 days storage in $\mathrm{Na}_{2} \mathrm{SO}_{4}$ solution.

\begin{tabular}{ccccccc}
\hline \multirow{2}{*}{ Cement } & \multirow{2}{*}{ CEM I } & $\begin{array}{c}\text { CEM } \\
\text { I-SR3 }\end{array}$ & $\begin{array}{c}\text { CEM I } \\
\text { FA }\end{array}$ & $\begin{array}{c}\text { CEM } \\
\text { II/B-S }\end{array}$ & $\begin{array}{c}\text { CEM III/A } \\
\text { (1) }\end{array}$ \\
\hline \multirow{2}{*}{$\mathbf{R}^{\mathbf{2}}$} & & $\mathbf{1 7 \%}$ & $\mathbf{3 4 \%}$ & $\mathbf{6 8 \%}$ & $\mathbf{4 5 \%}$ & $\mathbf{3 1 \%}$ \\
\hline \multirow{3}{*}{ contribution } & $\mathrm{T}$ & & & $33 \%$ & & \\
& $\mathrm{c}$ & n. d. & n. d. & $1 \%$ & n. d. & n. d. \\
& $\mathrm{T}^{2}$ & & & $54 \%$ & & \\
& b.c & & & $34 \%$
\end{tabular}

T: temperature, $b$ : binder content, c: sulfate concentration, $n$. d.: not determined ${ }^{(1)}$ influence of binder content not considered in this series.

The reason for the inability to determine good models for the relative flexural strength is the low diversification of the measurement data. At $182 \mathrm{~d}$, there were no significant changes in flexural strength under the examined test conditions detected.

At a water to binder ratio of 0.50 , the differences between the measured flexural strength samples after 182 days storage were still not large enough to allow for a good assessment of the deterioration, as shown in Figure 5. The remaining relative flexural strength after storage at $5{ }^{\circ} \mathrm{C}$ in $6000 \mathrm{mg} \mathrm{SO}{ }_{4}{ }^{2-} / \mathrm{L}$ sodium sulfate solution was $8 \%$ for concrete with Portland cement and $116 \%$ for concrete with Portland cement and fly ash. It can be concluded that six months of storage was most likely too short to evaluate the sulfate resistance of concrete by flexural strength measurements.

\subsubsection{Tensile Strength}

For the series with CEM I that was expected to be most susceptible to sulfate induced deterioration, a regression model of acceptable quality could be calculated for the relative tensile strength of concrete with $\mathrm{w} / \mathrm{c}=0.45$ after 182 days of storage (cf. Table 7). No influence of the binder content on the models could be observed. The models for concrete with CEM I and CEM I + FA are predominantly influenced by the temperature during storage. For the series with CEM I, a significant influence of the sulfate concentration could also be detected (10\% contribution). For the series CEM I-SR3 and CEM II/B-S, no models of acceptable quality could be found for the relative tensile strength. 
rel. flexural strength $f_{f} / f_{f}$

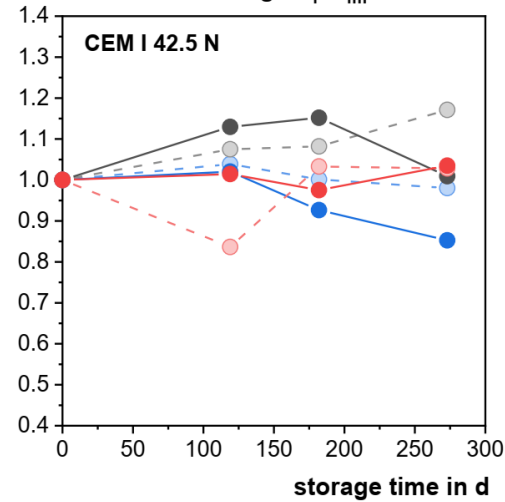

rel. flexural strength $f_{f} / f_{f m}$

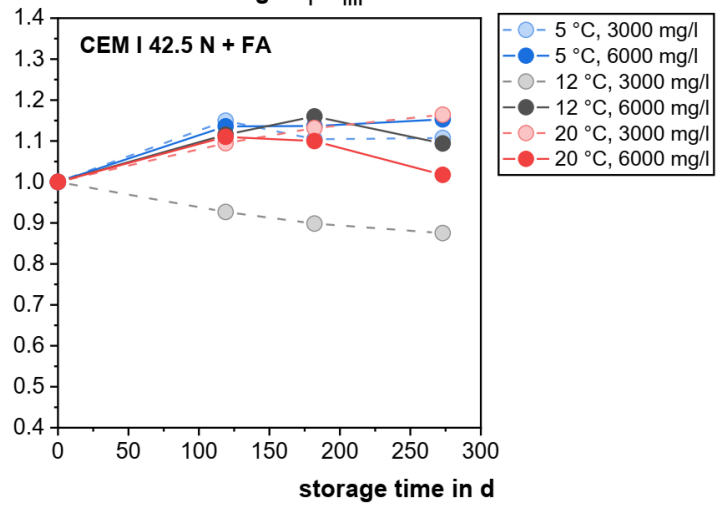

Figure 5. Relative flexural strength (ref.: maturity function) of concrete with CEM I $42.5 \mathrm{~N}$ and CEM I $42.5 \mathrm{~N}+\mathrm{FA}$ $\left(\mathrm{w} / \mathrm{c}_{\mathrm{eq}}=0.50\right)$ after storage in $\mathrm{Na}_{2} \mathrm{SO}_{4}$ solution.

Table 7. Coefficient of variation $\mathrm{R}^{2}$ and contribution of independent variables/interactions for regression models of the relative tensile strength $\left(\mathrm{f}_{\mathrm{t}} / \mathrm{f}_{\mathrm{tm}}\right)$ of concrete with $\mathrm{w} / \mathrm{c}=0.45$ after 182 days storage in $\mathrm{Na}_{2} \mathrm{SO}_{4}$ solution.

\begin{tabular}{|c|c|c|c|c|c|c|}
\hline \multicolumn{2}{|c|}{ Cement } & CEM I & CEM I-SR3 & CEM I + FA & CEM II/B-S ${ }^{(1)}$ & CEM III/A ${ }^{(1)}$ \\
\hline \multicolumn{2}{|c|}{$\mathbf{R}^{2}$} & $54 \%$ & $16 \%$ & $61 \%$ & $12 \%$ & $54 \%$ \\
\hline \multirow{6}{*}{ contribution } & $\mathrm{T}$ & 6 & \multirow{6}{*}{ n. d. } & 49 & \multirow{6}{*}{ n. d. } & n. i. \\
\hline & c & 10 & & n. i. & & 26 \\
\hline & $\rho$ & n. i. & & n. i. & & 18 \\
\hline & $\mathrm{T}^{2}$ & 36 & & 6 & & n. i. \\
\hline & $\mathrm{T} \cdot \rho$ & 4 & & 8 & & n. i. \\
\hline & $c \cdot \rho$ & n. i. & & n. i. & & 14 \\
\hline
\end{tabular}

T: temperature, c: sulfate concentration, $\rho$ : fresh concrete density, n. d.: not determined, $n$. i.: no influence ${ }^{(1)}$ influence of binder content not considered in this series.

The mathematical model as well as the underlying data for the series CEM I (cf. Figure 6) show that the higher sulfate concentration of the sodium sulfate solution results in a lower relative strength for all three tested temperatures. The predominant influence of the temperature is described by a parabolic function. The highest relative strength was observed at $12{ }^{\circ} \mathrm{C}$ storage temperature (average $\mathrm{f}_{\mathrm{t}} / \mathrm{f}_{\mathrm{tm}}=1.08$ ), while lower strengths can be seen at $5{ }^{\circ} \mathrm{C}$ (average $\left.\mathrm{f}_{\mathrm{t}} / \mathrm{f}_{\mathrm{tm}}=0.91\right)$ and $20^{\circ} \mathrm{C}\left(\right.$ average $\left.\mathrm{f}_{\mathrm{t}} / \mathrm{f}_{\mathrm{tm}}=0.98\right)$. The higher relative strength at $12^{\circ} \mathrm{C}$ can possibly be explained by the initial densifying effect of ettringite and gypsum before the samples deteriorate. After storage at $20^{\circ} \mathrm{C}$, the samples are mostly unaffected, while at $5{ }^{\circ} \mathrm{C}$ the specimens increasingly deteriorate, causing the reduced strength.

The dominant influence of the temperature is also apparent in the model and underlying data for series CEM I + FA (see Figure 7, right). Since there is no apparent influence by any other predictor apart from the temperature, the model shows a parabolic correlation between the temperature and the relative tensile strength. The original measurement data shown in the Figure 7 (left) confirms the validity of the calculated model. At $20^{\circ} \mathrm{C}$, the formation of ettringite and gypsum reduces the porosity and thereby improves the strength of the concrete, whereas at $5{ }^{\circ} \mathrm{C}$ this effect at longer storage times is counteracted by the loss in strength due to cracking caused by the increasing crystallization pressure (cf. Section 3.3) owing to a higher thermodynamic stability of ettringite at lower temperatures [35]. For both series, it can be concluded that the lower storage temperature of $5^{\circ} \mathrm{C}$ accelerates the strength loss. 


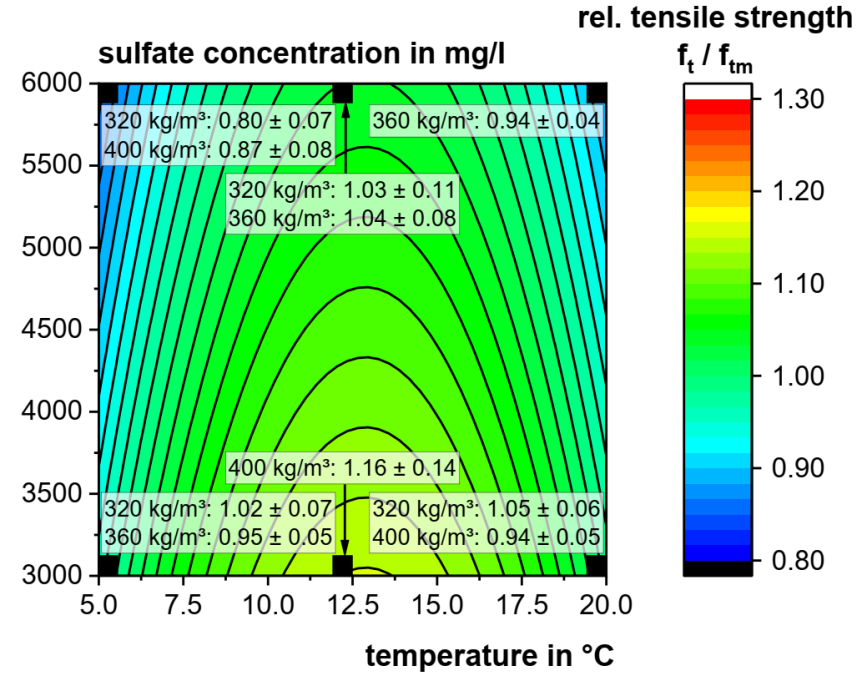

Figure 6. Tensile strength (ref.: maturity function) of concrete with CEM I $42.5 \mathrm{~N}$ and w/c $=0.45$ after 182 days storage in $\mathrm{Na}_{2} \mathrm{SO}_{4}$ solution.
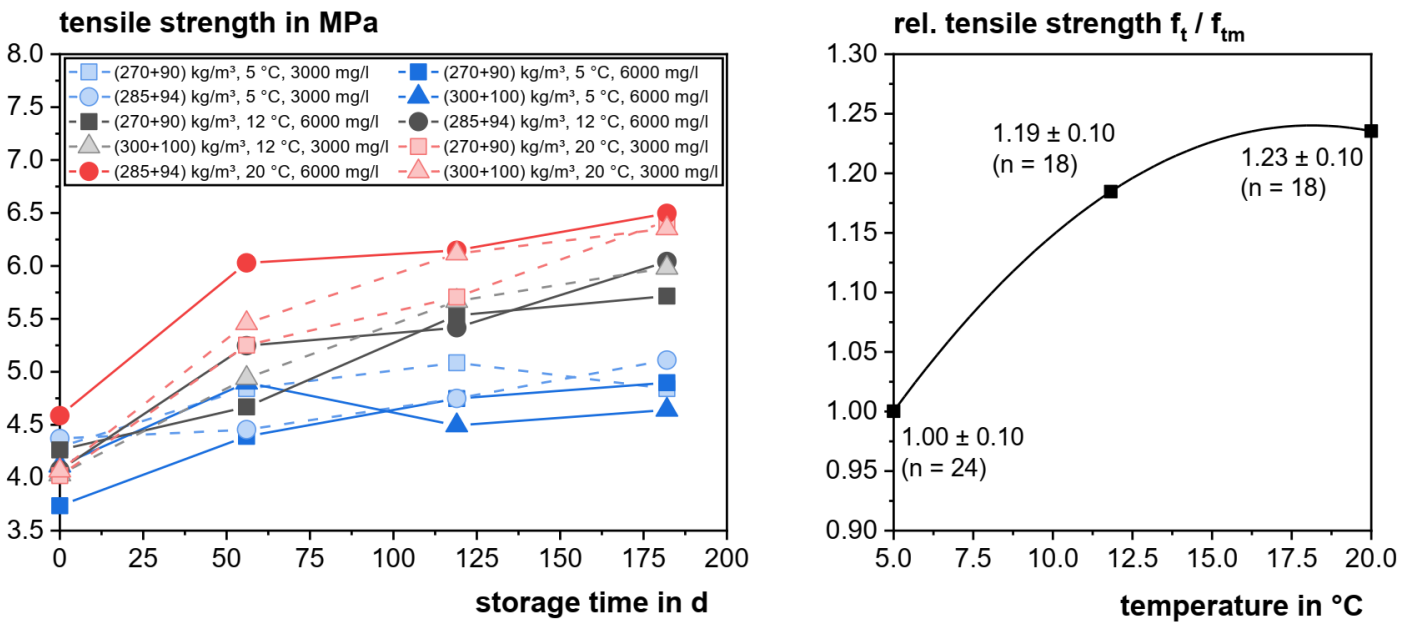

Figure 7. Tensile strength (left) and calculated regression model for the relative tensile strength (182 d, ref.: maturity function) of concrete with CEM I $42.5 \mathrm{~N}+\mathrm{FA}$ and $\mathrm{w} / \mathrm{c}$ eq $=0.45$ after storage in $\mathrm{Na}_{2} \mathrm{SO}_{4}$ solution.

The model for CEM III/A solely predicts the sulfate concentration as an influence on the relative tensile strength. Due to this relatively small variation compared to the differences described for CEM I and CEM I + FA and the apparent influence of the fresh concrete density, the calculated model should be considered with caution (cf. Table 7).

Due to the slightly higher water to binder ratio of 0.50 (concrete mixtures M7/M8, Table 3), the dominant influence of the temperature on the relative tensile strength is more pronounced, as can be seen in Figure 8. This is especially the case for storage in $6000 \mathrm{mg}$ $\mathrm{SO}_{4}{ }^{2-} / \mathrm{L}$. For concrete with CEM I $42.5 \mathrm{~N}$ stored at $5{ }^{\circ} \mathrm{C}$ and $6000 \mathrm{mg} \mathrm{SO}_{4}{ }^{2-} / \mathrm{L}$, the relative tensile strength drops significantly from 1.09 after 119 days to 0.78 after 182 days $(|\mathrm{t}|=9.87$, $p=0.05)$ and further to 0.50 after 273 days $(|\mathrm{t}|=5.55, p=0.05)$. The loss in tensile strength is less intense for concrete with CEM I $42.5 \mathrm{~N}-\mathrm{SR} 3$, yet the changes are still significant $(|\mathrm{t}|=4.21$ from 119 day to 182 days and $|\mathrm{t}|=3.77$ from 182 days to 273 days, $p=0.05)$. The relative tensile strength after 273 days of storage at these conditions is 0.64 . 
rel. tensile strength $f_{t} / f_{t m}$

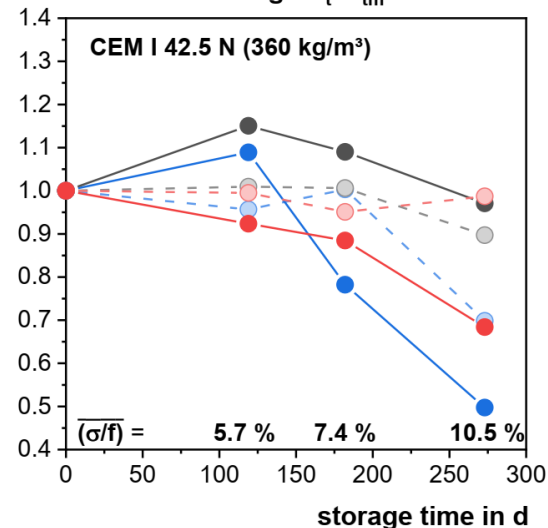

rel. tensile strength $f_{t} / f_{t m}$
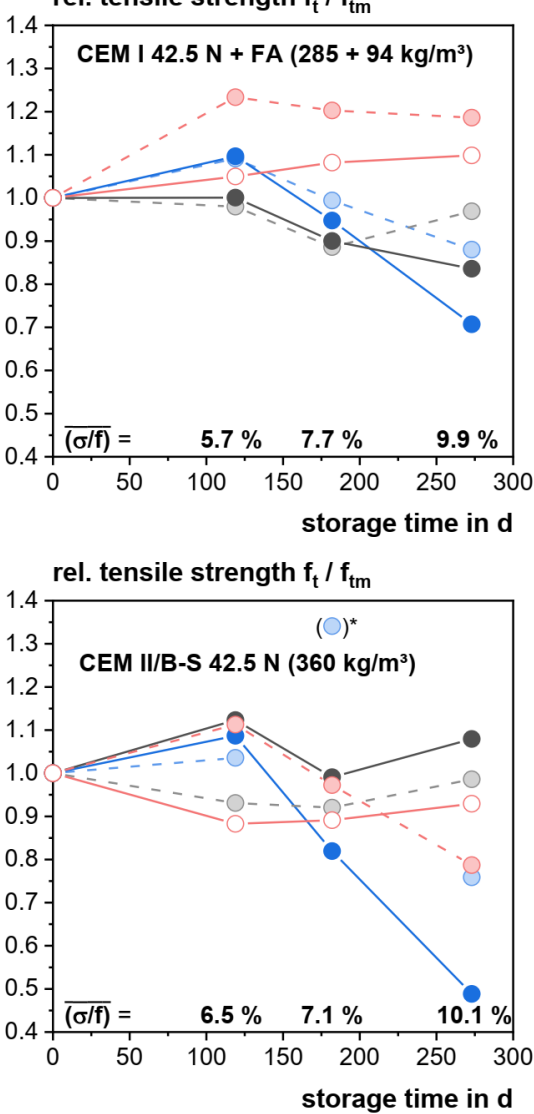

rel. tensile strength $f_{t} / f_{t m}$

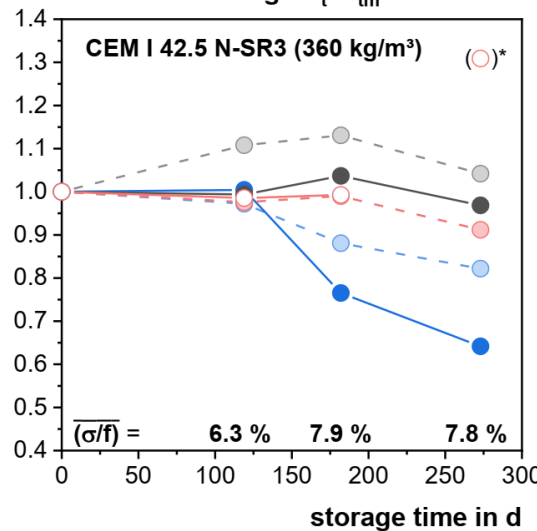

rel. tensile strength $f_{t} / f_{t m}$

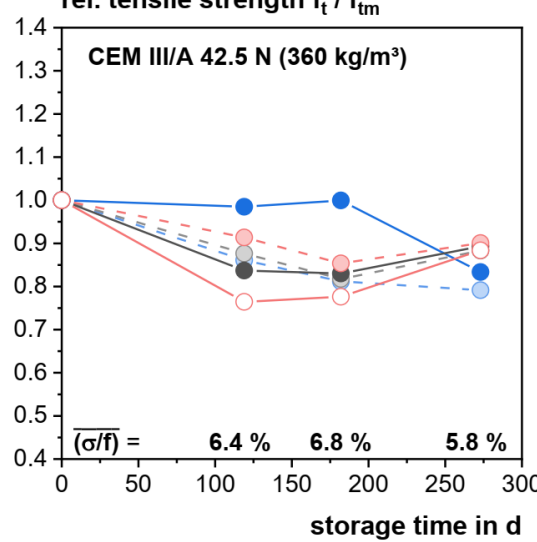

Figure 8. Relative tensile strength (ref.: maturity function) of concrete with $\mathrm{w} / \mathrm{c}_{\mathrm{eq}}=0.50$ after storage in $\mathrm{Na}_{2} \mathrm{SO}_{4}$ solution.

For the concrete samples containing CEM I, there is an overall tendency towards significant strength loss in the period between 182 and 273 days of storage. Apart from the specimen stored at $20^{\circ} \mathrm{C}$ in $3000 \mathrm{mg} \mathrm{SO}{ }_{4}{ }^{2-} / \mathrm{L}$ sodium sulfate solution, all mixtures experience significant strength loss. That is not the case for the sulfate resistant CEM I-SR3: the only significant changes, apart from the aforementioned strength loss at $5{ }^{\circ} \mathrm{C}$ in $6000 \mathrm{mg} \mathrm{SO}{ }^{2-} / \mathrm{L}$, can be observed between 119 days and 182 days for $5^{\circ} \mathrm{C}$ at $3000 \mathrm{mg}$ $\mathrm{SO}_{4}{ }^{2-} / \mathrm{L}(|\mathrm{t}|=2.58, p=0.05)$ and for the specimen stored at $20^{\circ} \mathrm{C}$ in $6000 \mathrm{mg} \mathrm{SO}_{4}{ }^{2-} / \mathrm{L}$ solution $(|\mathrm{t}|=5.04, p=0.05)$.

A similar behavior to the CEM I-SR3 series can be observed for the concrete samples produced with a combination of Portland cement and fly ash. The strength loss for samples stored at $5{ }^{\circ} \mathrm{C}$ in $6000 \mathrm{mg} \mathrm{SO}{ }^{2-} / \mathrm{L}$ sodium sulfate solution is significant for the interval between 119 and 182 days $(|\mathrm{t}|=2.63, p=0.05)$ as well as between 182 and 273 days 
$(|t|=3.05, p=0.05)$. The remaining relative strength is 0.71 and hence slightly above the level of the CEM I-SR3 series.

The storage of concrete with CEM II/B-S at $5{ }^{\circ} \mathrm{C}$ in $6000 \mathrm{mg} \mathrm{SO}_{4}{ }^{2-} / \mathrm{L}$ results in a relative strength loss comparable to the CEM I series. The relative strength drops significantly from 1.09 after 119 days to 0.82 after 182 days $(|\mathrm{t}|=8.07, p=0.05)$ and to 0.49 after 273 days $(|t|=6.22, p=0.05)$. Compared to the other binders, no big decrease in relative strength can be observed for concrete with CEM III/A, which proves the expected good sulfate resistance of this mixture.

To summarize the results on tensile strength testing as a benchmark for the sulfate resistance of concrete, in Figure 9, the results for storage in $6000 \mathrm{mg} \mathrm{SO}_{4}{ }^{2-} / \mathrm{L}$ sodium sulfate solution at $5{ }^{\circ} \mathrm{C}$ are depicted for both mix designs (w/c $=0.45$ and 0.50 ). The markers indicate measured data, while the lines represent interpolated and extrapolated data.

rel. tensile strength $f_{t} / f_{t m}$

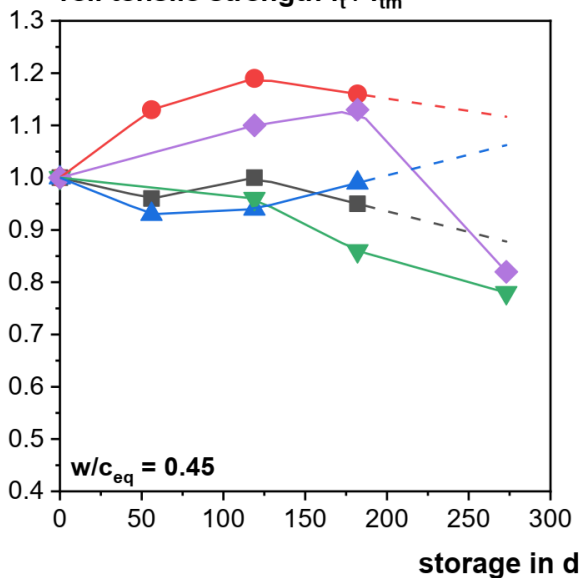

rel. tensile strength $f_{t} / f_{t m}$

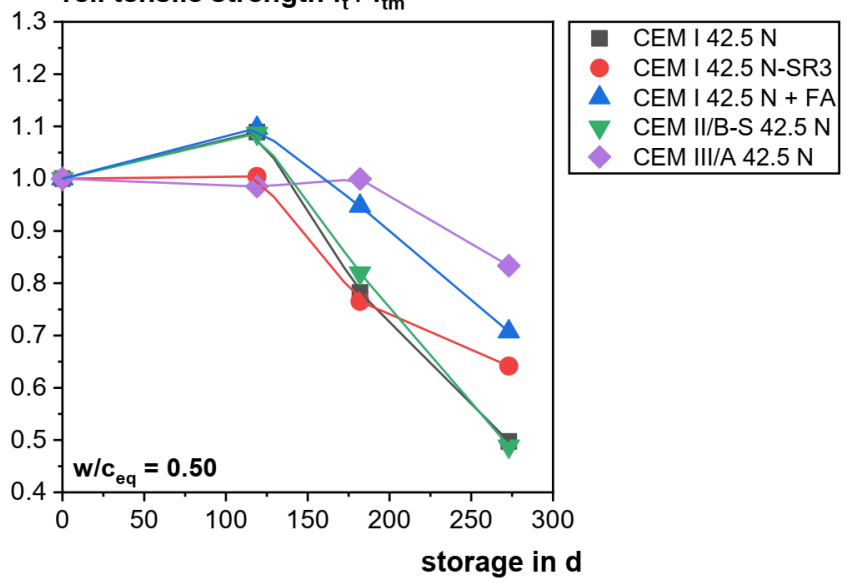

Figure 9. Relative tensile strength (ref.: maturity function) of the concretes with $\mathrm{w} / \mathrm{c}_{\mathrm{eq}}=0.45 \mathrm{and} \mathrm{w} / \mathrm{c}_{\mathrm{eq}}=0.50$ after storage in $\mathrm{Na}_{2} \mathrm{SO}_{4}$ solution with $6000 \mathrm{mg} \mathrm{SO}{ }_{4}{ }^{2-} / \mathrm{L}$ at $5{ }^{\circ} \mathrm{C}$ (dashed lines: extrapolated data).

The increase in porosity caused by the higher water to binder ratio resulted in greater variability of the relative tensile strength data, which allows a better differentiation between the series. Enhancing the time for storage in the sulfate solution results in a further degradation of the specimens, which allows for a better evaluation of the measured data. Low relative final strength was observed for concrete with CEM I and CEM II/B-S, while the concrete with CEM I-SR3 performed slightly better, as well as a mixture of CEM I and fly ash. The highest remaining final tensile strength was detected for concrete with CEM III/A, proving the higher sulfate resistance of this concrete series.

\subsection{Microstructural Analysis}

In Figure 10, SEM images of the fractured surface of a concrete sample made with CEM I $42.5 \mathrm{~N}$ and from concrete with CEM I $42.5 \mathrm{~N}-\mathrm{SR} 3$ stored for 182 days in $6000 \mathrm{mg}$ $\mathrm{SO}_{4}{ }^{2-} / \mathrm{L}$ sodium sulfate solution are shown. Large cracks can be observed on the outside of the specimen with CEM I $42.5 \mathrm{~N}$. The crack system runs from the surface into the center of the sample. The bigger pores close to the surface unto a depth of 1 to $2 \mathrm{~mm}$ are usually filled with sulfate-rich phases, predominantly large crystals of gypsum (cf. Figure 11). In the cracks, large hexagonal crystals of ettringite can be observed. The assignment of mineralogical phases was made with the help of EDX measurements. Larger cracks have a width of up to $5 \mu \mathrm{m}$ and are wider than the cracks of 1-1.5 $\mu \mathrm{m}$ that are present in the specimen with CEM I $42.5 \mathrm{~N}-\mathrm{SR} 3$ at a similar depth. 

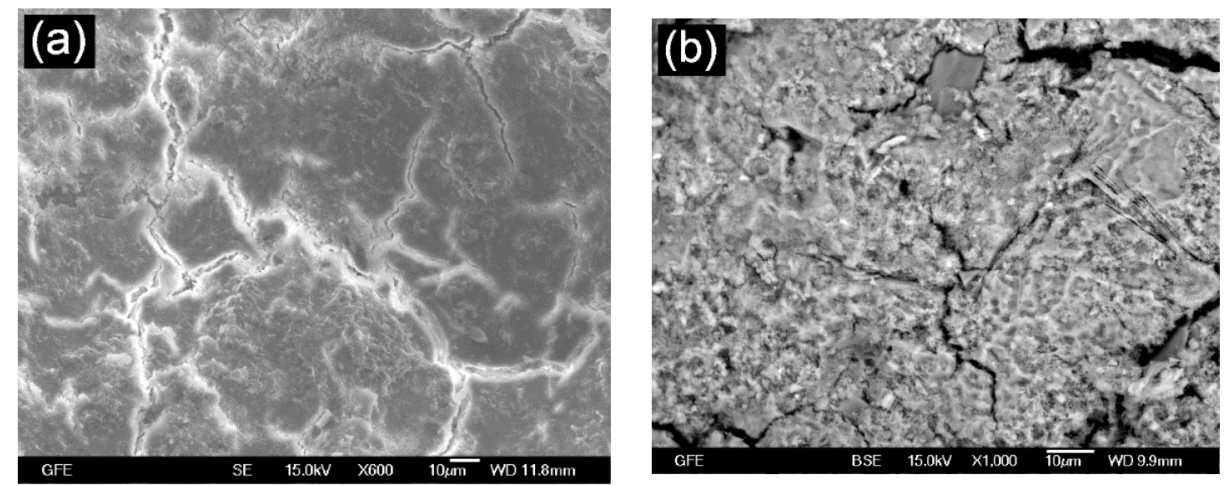

Figure 10. SEM micrographs (1 mm depth) of concrete with (a) CEM I $42.5 \mathrm{~N}$ and (b) CEM I 42.5 $\mathrm{N}-\mathrm{SR} 3(\mathrm{w} / \mathrm{c}=0.50)$ stored for $182 \mathrm{~d}$ at $5{ }^{\circ} \mathrm{C}$ in $\mathrm{Na}_{2} \mathrm{SO}_{4}$ solution with $6000 \mathrm{mg} \mathrm{SO}_{4}{ }^{2-} / \mathrm{L}$.

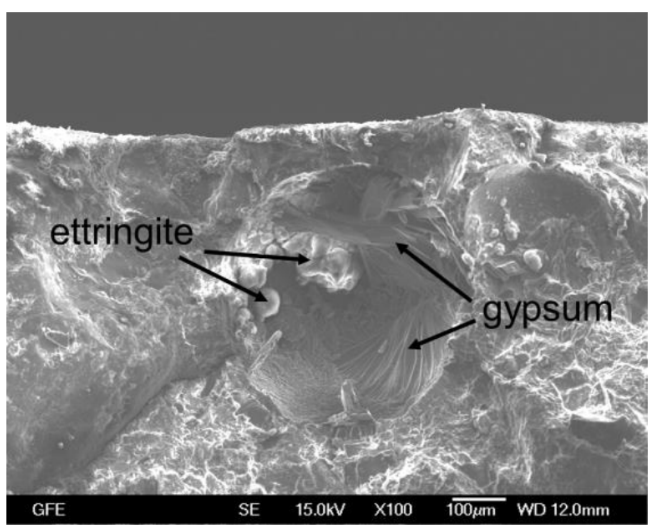

Figure 11. SEM micrographs (surface) of concrete with CEM I $42.5 \mathrm{~N}(\mathrm{w} / \mathrm{c}=0.50)$ stored for $182 \mathrm{~d}$ at $5^{\circ} \mathrm{C}$ in $\mathrm{Na}_{2} \mathrm{SO}_{4}$ solution with $6000 \mathrm{mg} \mathrm{SO}_{4}{ }^{2-} / \mathrm{L}$.

Towards the center of the samples, portlandite could be found throughout all specimens. Portlandite is not present on the surface of the specimen stored in sulfate solution because of leaching. In samples with CEM II/B-S, monosulphoaluminate (AFm) could be identified starting at a depth of $2 \mathrm{~mm}$ (cf. Figure 12).
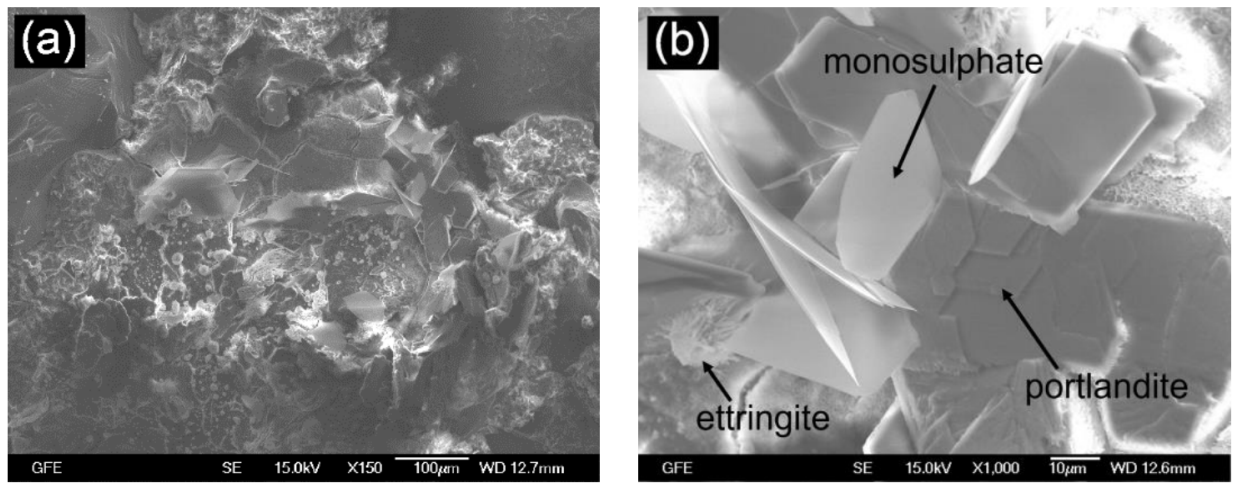

Figure 12. SEM micrographs (2 mm depth, (a) overview and (b) detail) of concrete with CEM II/B-S $42.5 \mathrm{~N}(\mathrm{w} / \mathrm{c}=0.50)$ stored for $182 \mathrm{~d}$ at $5{ }^{\circ} \mathrm{C}$ in $\mathrm{Na}_{2} \mathrm{SO}_{4}$ solution with $6000 \mathrm{mg} \mathrm{SO}_{4}{ }^{2-} / \mathrm{L}$.

The crack system for the specimen with CEM III/ A was less pronounced compared to the other samples, as can be seen in Figure 13. Near the surface, ettringite and gypsum could be seen in pores and cracks. However, the sulfate intrusion depth seemed to be much lower. 


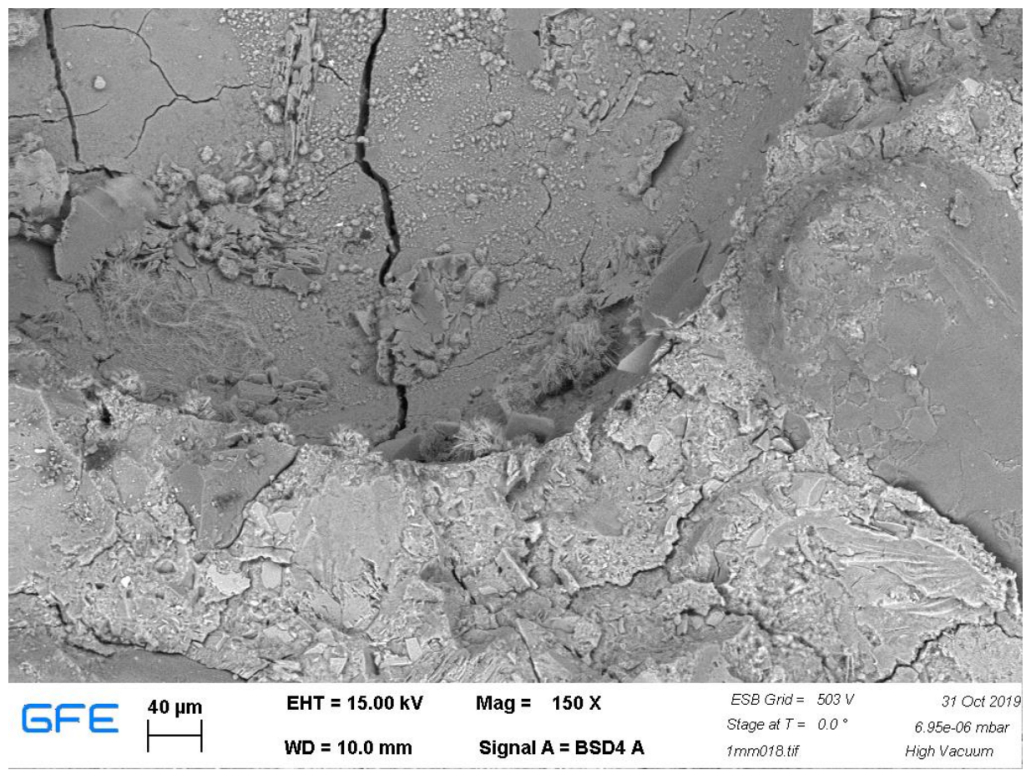

Figure 13. SEM micrograph (1 mm depth) of concrete with CEM III/A $42.5 \mathrm{~N}$ (w/c $=0.50)$ stored for $182 \mathrm{~d}$ at $5{ }^{\circ} \mathrm{C}$ in $\mathrm{Na}_{2} \mathrm{SO}_{4}$ solution with $6000 \mathrm{mg} \mathrm{SO}{ }_{4}{ }^{2-} / \mathrm{L}$.

In addition to the micrographs on fractured surfaces, EDX area scans were created on polished sections of samples that were embedded in epoxy resin. Aggregates were identified after determining a threshold of $75 \mathrm{wt} \% \mathrm{Si}$ and are represented as black areas in the graphs. Similarly, the epoxy resin present on the surface and in pores as well as in cracks was distinguished from the sample by combining suitable EDX images to enhance the contrast. Areas with epoxy resin are filled in dark blue. The resulting diagrams (Figures 14 and 15) represent the quantitative EDX analysis. The color level indicates the content of the element in the respective spot. Depth profiles of sulfur and calcium were calculated as average of a given depth, not including the aggregate and epoxy resin.

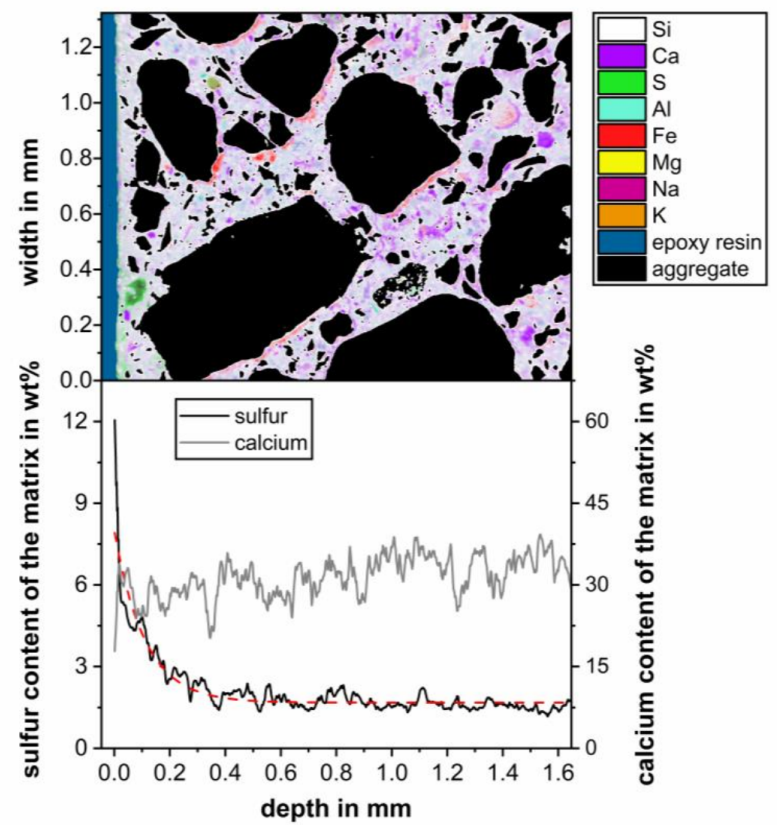

Figure 14. EDX map of a concrete sample with CEM I $42.5 \mathrm{~N}(\mathrm{w} / \mathrm{c}=0.50)$ stored for $182 \mathrm{~d}$ at $5{ }^{\circ} \mathrm{C}$ in $\mathrm{Na}_{2} \mathrm{SO}_{4}$ solution with $6000 \mathrm{mg} \mathrm{SO}_{4}{ }^{2-} / \mathrm{L}$ and corresponding depth profile. 


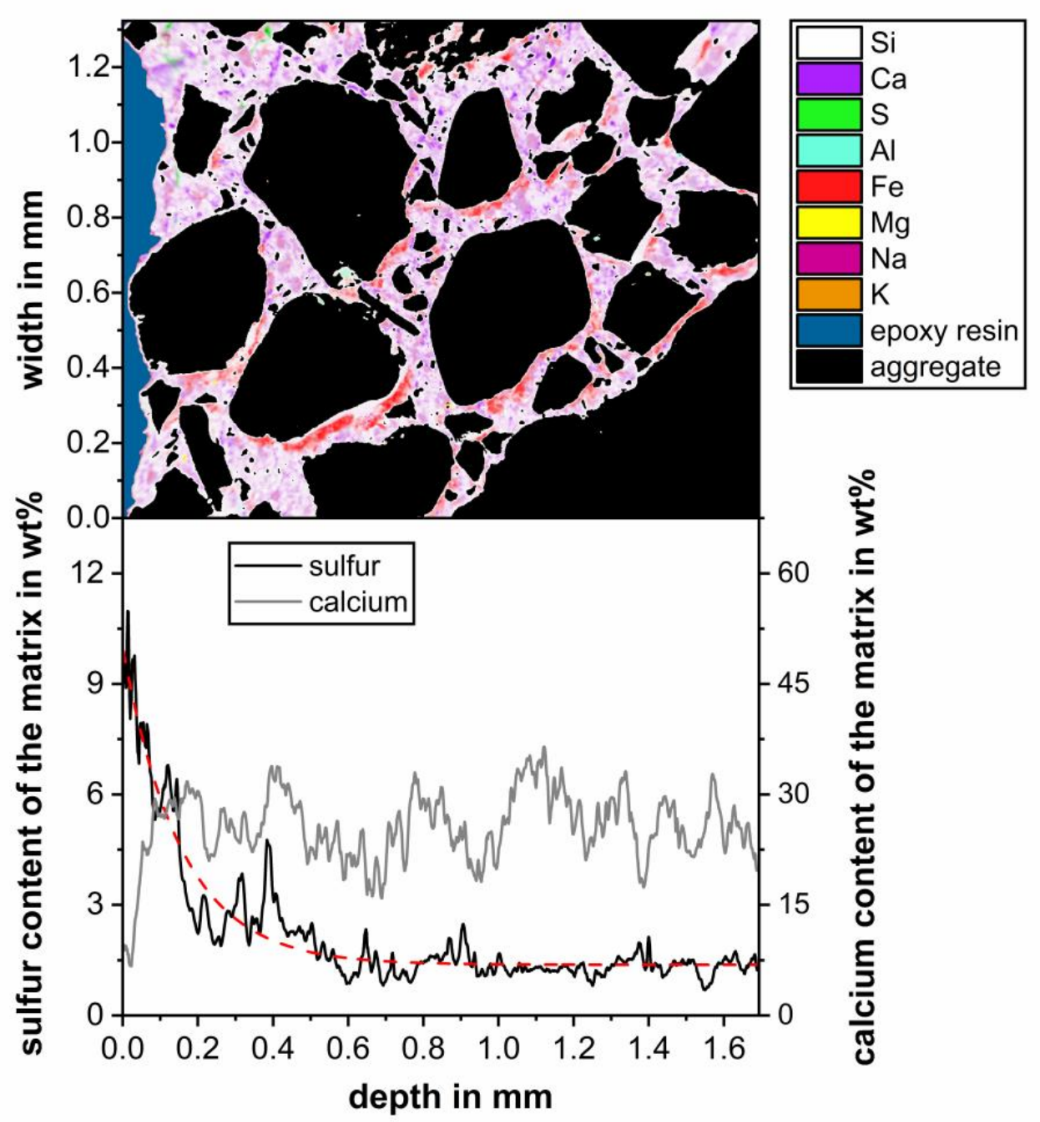

Figure 15. EDX map of a concrete sample with CEM I $42.5 \mathrm{~N}-\mathrm{SR} 3(\mathrm{w} / \mathrm{c}=0.50)$ stored for $182 \mathrm{~d}$ at $5{ }^{\circ} \mathrm{C}$ in $\mathrm{Na}_{2} \mathrm{SO}_{4}$ solution with $6000 \mathrm{mg} \mathrm{SO}_{4}{ }^{2-} / \mathrm{L}$ and corresponding depth profile.

In Figure 14, the EDX area scan of a concrete sample with CEM I $42.5 \mathrm{~N}$ after storage for 182 days in $\mathrm{Na}_{2} \mathrm{SO}_{4}$ solution is shown. Near the surface of the sample, pores with large amounts of sulfur can be seen, and the calcium level is relatively low due to the leaching of calcium by the sulfate solution. Towards the inside of the sample, the calcium content increases slightly, as more portlandite is present in the pore structure. Red areas below the aggregate are a measurement artifact due to insufficient signal strength on the detector. This was caused by the texturization of the sample surface due to the different hardness of aggregate and matrix and its effect on the grinding process.

The dashed red line serves as an eye guide for the sulfur depth profile. On the surface of the sample the sulfur content of the matrix is about $12 \mathrm{wt} \%$. It decreases drastically with increasing depth within the first half millimeter. At a depth of $0.8 \mathrm{~mm}$, a sulfur content of $1.7 \mathrm{wt} \%$ was calculated, which stays constant until the end of the inspected area.

The sulfur concentration in the matrix on the surface of the sample with sulfate resistant CEM I $42.5 \mathrm{~N}-\mathrm{SR} 3$ is about the same compared to the specimen with CEM I $42.5 \mathrm{~N}$, as can be seen in Figure 15. Cracks filled with gypsum can be seen in the top left corner of the EDX area scan. A slower decrease in sulfur content was calculated compared to the CEM I sample until a depth of $1 \mathrm{~mm}$. However, the average sulfur content at this point is slightly lower at a level of $1.4 \mathrm{wt} \%$.

The average calcium content of the matrix is lower, which might be an indication of more pronounced leaching since the calcium content of the cements are similar. These results must be considered with caution since no representative sampling was done.

The similarity between the degradation of CEM I and CEM I-SR3 concretes can also be confirmed by the $\mathrm{SO}_{3}$ and XRD depth profiles, as can be seen in Figure 16. The sulfate ingress on the surface is a little higher for the CEM I sample (2.9 $\mathrm{wt} \%$ ) compared to the CEM I-SR3 sample (2.4 wt\%). At a depth of $4-5 \mathrm{~mm}$, the specimen with CEM I contained 
$0.6 \mathrm{wt} \%$ of $\mathrm{SO}_{3}$ whereas $0.8 \%$ by mass is present in the CEM I-SR3 specimen. This difference is explained by a higher ettringite content of the sample with CEM I $42.5 \mathrm{~N}-\mathrm{SR} 3$ at this depth level. The results are in line with those obtained from the EDX area scans.

content in wt $\%$

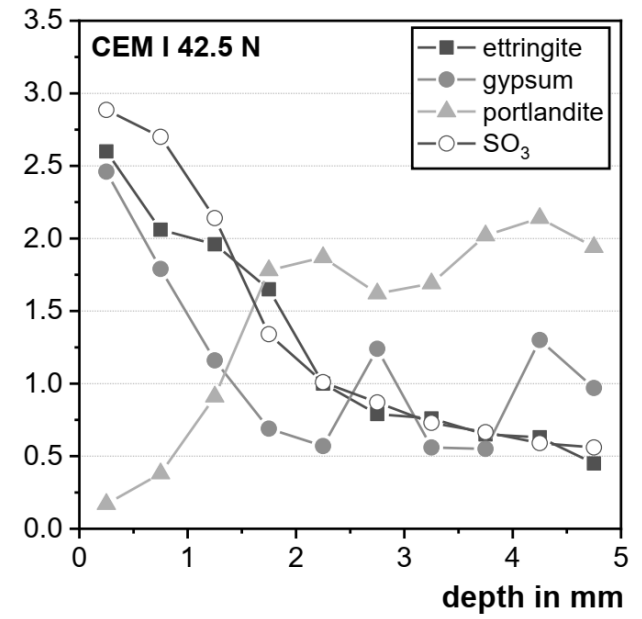

content in wt $\%$

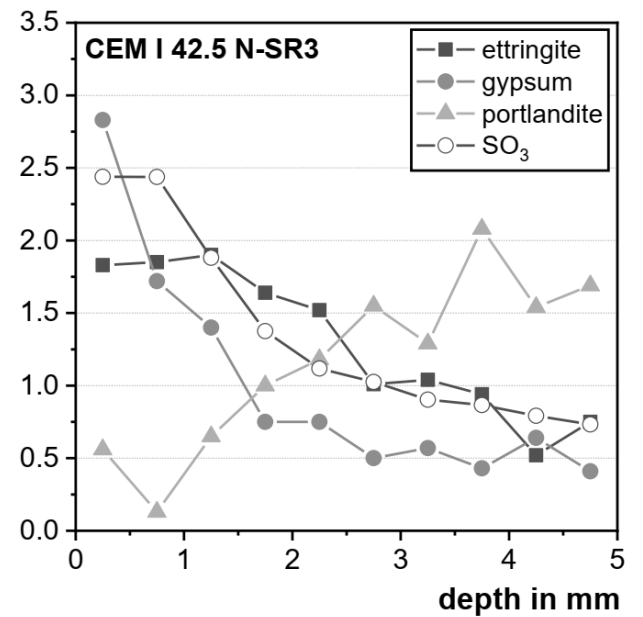

Figure 16. Ettringite, gypsum, portlandite content (XRD) and $\mathrm{SO}_{3}$ content (carbon/sulfur analysis) over the depth of the specimen with CEM I $42.5 \mathrm{~N}$ and CEM I $42.5 \mathrm{~N}-\mathrm{SR} 3(\mathrm{w} / \mathrm{c}=0.50)$ stored for $182 \mathrm{~d}$ at $5{ }^{\circ} \mathrm{C}$ in $\mathrm{Na}_{2} \mathrm{SO}_{4}$ solution with $6000 \mathrm{mg} \mathrm{SO}{ }_{4}^{2-} / \mathrm{L}$.

Compared to depth profiles of specimens stored in $3000 \mathrm{mg} \mathrm{SO}_{4}{ }^{2-} / \mathrm{L}$ sodium sulfate solution (cf. [30]), a slightly higher content of gypsum was observed up to a depth of about $2 \mathrm{~mm}$. These results are in agreement with studies by Bellmann et al. [36] which showed that, at very low sulfate concentrations ( $1500 \mathrm{mg} \mathrm{SO}_{4}{ }^{2-} / \mathrm{L}$ ), the formation of gypsum is suppressed. With increasing sulfate concentration, the formation of gypsum gets more pronounced, eventually leading to gypsum being the dominant reason for deterioration at very high levels around $30,000-50,000 \mathrm{mg} \mathrm{SO}_{4}{ }^{2-} / \mathrm{L}$. The sulfate concentration level of $6000 \mathrm{mg} \mathrm{SO}_{4}{ }^{2-} / \mathrm{L}$ therefore constitutes a compromise between the realistic representation of the damage mechanism in the field and the acceleration of the deterioration process.

The incorporation of fly ash into the mix reduces the ingress of sulfate into the concrete and leads to less gypsum and ettringite formation in the outer region of the sample (cf. Figure 17). Due to the pozzolanic reaction, the portlandite content on the inside is lower compared to the sample with Portland cement as the only binder. The ettringite level at a depth of $4-5 \mathrm{~mm}$ is very low at $0.2 \mathrm{wt} \%$, which is confirmed by the comparably lower $\mathrm{SO}_{3}$ content of $0.5 \mathrm{wt} \%$ determined by carbon/sulfur analysis.

The concrete with CEM II/B-S $42.5 \mathrm{~N}$ shows the highest ettringite content $(3.0 \mathrm{wt} \%)$ on the surface as well as a very low level of gypsum at $1.4 \%$ by mass (see Figure 18). This is probably caused by the slag addition to the clinker that can lead to a reduced sulfate resistance of cement and concrete at low replacement levels [37], as was also confirmed by the relative tensile strength loss of the samples containing CEM II/B-S shown in Figure 8. The small depth of leaching of the concrete with CEM III/ A $42.5 \mathrm{~N}$ can be derived from the depth profile of portlandite, proving the high physical resistance against sulfate attack of this mixture. The slightly higher $\mathrm{SO}_{3}$ content compared to the samples with Portland cement is caused by the sulfides present in the blast furnace slag. 
content in wt\%

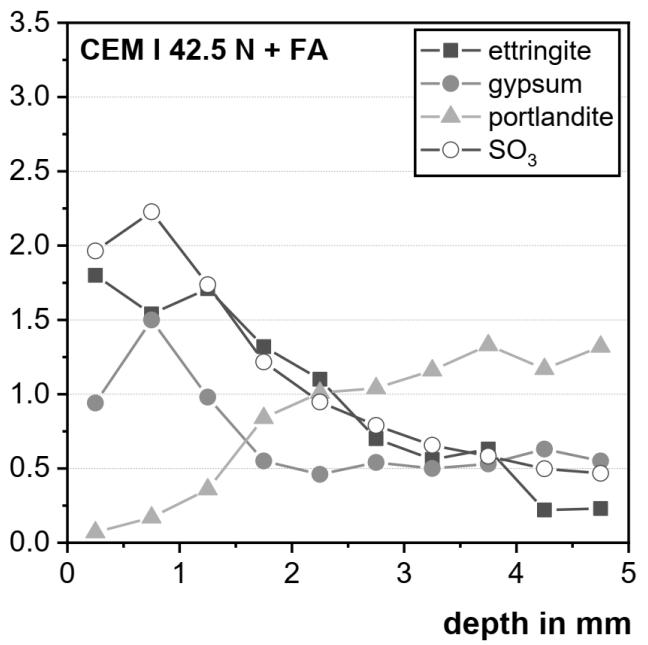

Figure 17. Ettringite, gypsum, portlandite content (XRD) and $\mathrm{SO}_{3}$ content (carbon/sulfur analysis) over the depth of the specimen with CEM I $42.5 \mathrm{~N}+\mathrm{FA}(\mathrm{w} / \mathrm{c}=0.50)$ stored for $182 \mathrm{~d}$ at $5{ }^{\circ} \mathrm{C}$ in $\mathrm{Na}_{2} \mathrm{SO}_{4}$ solution with $6000 \mathrm{mg} \mathrm{SO}_{4}{ }^{2-} / \mathrm{L}$.
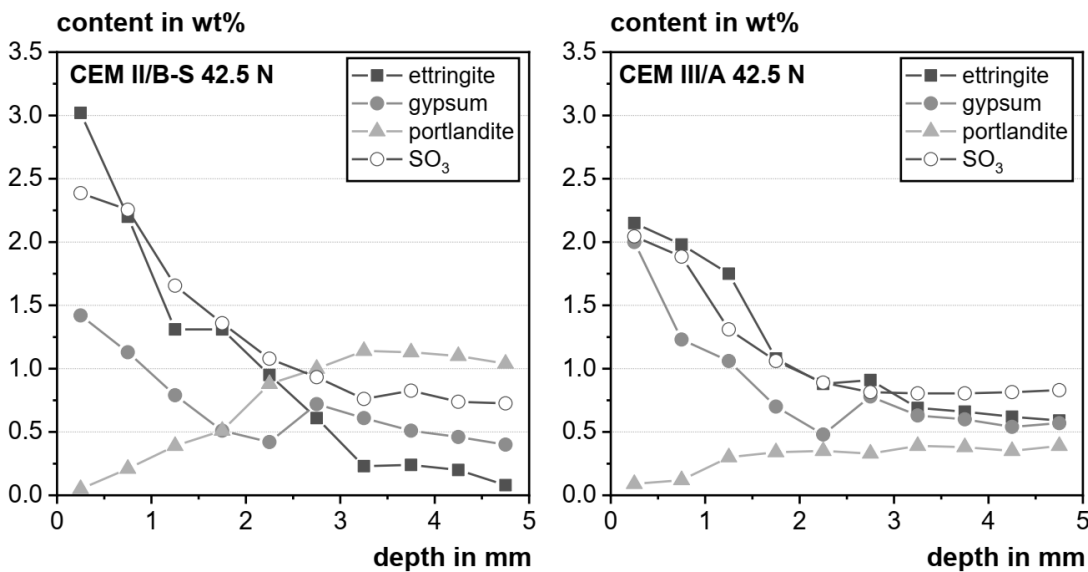

Figure 18. Ettringite, gypsum, portlandite content (XRD) and $\mathrm{SO}_{3}$ content (carbon/sulfur analysis) over the depth of the specimen with CEM II/B-S $42.5 \mathrm{~N}$ and CEM III/A $42.5 \mathrm{~N}$ (w/c = 0.50) stored for $182 \mathrm{~d}$ at $5{ }^{\circ} \mathrm{C}$ in $\mathrm{Na}_{2} \mathrm{SO}_{4}$ solution with $6000 \mathrm{mg} \mathrm{SO}_{4}{ }^{2-} / \mathrm{L}$.

\section{Conclusions and Implications for a Future Testing Procedure}

The focus of the parametric study in this publication was to develop a test set-up based on tensile strength testing, which allows a clear distinction between concrete that is sulfate resistant and not sulfate resistant. The idea was to use the relative tensile strength after storage in sulfate solution as a benchmark for the sulfate resistance of concrete.

Assessing the relative tensile strength in relation to reference samples stored in saturated lime solution has not proven to be beneficial. A high scatter was observed, and the results were not conclusive. Better results were achieved by utilizing the strength after curing of the specimen for 28 days as a reference. The suitability of a maturity function based on the fib model code was tested and proven to perform well in predicting the strength gain to be expected during the ongoing hydration of concrete. The compaction and the resulting density of the concrete have a strong influence on the tensile strength. Therefore, all samples should be produced from one batch of concrete and compacted equally. Segregation has to be avoided.

It was shown that the variation of the cement content in the concrete between 320 and $400 \mathrm{~kg} / \mathrm{m}^{3}$ does not significantly affect the strength loss after exposure in sulfate solution. 
The storage temperature seems to be of superior influence. The most severe loss in overall strength could be observed for storage at $5{ }^{\circ} \mathrm{C}$ in $6000 \mathrm{mg} \mathrm{SO}{ }_{4}{ }^{2-} / \mathrm{L}$ sodium sulfate solution. The authors therefore suggest the following test procedure to evaluate the sulfate resistance of concrete:

1. An adapted concrete mix design based on the planned concrete mixture should be used, while a maximum grain size of $8 \mathrm{~mm}$ must be adhered to.

2. The authors recommend raising the water to binder ratio by $10 \%$ to slightly reduce the density of the concrete, thus accelerating the performance test.

3. Briquette molds according to ASTM C307-03 should be used to produce the specimens for testing the tensile strength in one single batch, while after demolding, the samples must be stored in saturated $\mathrm{Ca}(\mathrm{OH})_{2}$ solution at $20^{\circ} \mathrm{C}$ until an age of 28 days.

4. The tensile strength of the concrete at an age of 28 days is determined and serves as the reference strength.

5. The specimens dedicated for sulfate storage are stored in sodium sulfate solution with $6000 \mathrm{mg} \mathrm{SO}{ }^{2-} / \mathrm{L}$ at $5{ }^{\circ} \mathrm{C}$ until testing. The storage solution is renewed every seven days until 28 days of storage and every 14 days afterwards to compensate the consumption of sulfates.

6. The tensile strength of the concrete is tested after 119 days (four months), 182 days (six months) and 273 days (nine months) of storage in the solution.

The relative tensile strength $\mathrm{f}_{t} / \mathrm{f}_{\mathrm{tm}}$ is calculated using the reference strength determined after curing for 28 days and the maturity function to account for the time of the samples in sulfate storage. The test procedure still must be verified for a large variety of binders.

Supplementary Materials: The following are available online at https:/ /www.mdpi.com/article/10 $.3390 /$ cryst11081001/s1. The data presented in this study are available in a digital supplement.

Author Contributions: Conceptualization, methodology, validation, formal analysis, investigation, data curation, visualization, writing — original draft preparation, J.H.; writing — review and editing, funding acquisition, supervision and advice, A.V.; supervision, T.M. All authors have read and agreed to the published version of the manuscript.

Funding: This research was funded by the AiF within the program for sponsorship by Industrial Joint Research (IGF) of the German Federal Ministry of Economic Affairs and Energy based on an enactment of the German Parliament (Project Nr. 19251N).

Data Availability Statement: The data presented in this study are available in Supplementary Materials.

Acknowledgments: This research was conducted in cooperation with the FEhS-Institut für BaustoffForschung e.V., Duisburg, Germany. We thank Andreas Ehrenberg and Volkert Feldrappe for the contribution of measurement data.

Conflicts of Interest: The authors declare no conflict of interest.

\section{References}

1. Skalny, J.; Marchand, J.; Odler, I. Sulfate Attack on Concrete; Spon Press: London, UK, 2002.

2. Santhanam, M. Effect of solution concentration on the attack of concrete by combined sulphate and chloride solutions. Eur. J. Environ. Civ. Eng. 2011, 15, 1003-1015. [CrossRef]

3. Yu, X.; Zhu, Y.; Liao, Y.; Chen, D. Study of the evolution of properties of mortar under sulfate attack at different concentrations. Adv. Cem. Res. 2016, 28, 617-629. [CrossRef]

4. DIN Deutsches Institut für Normung e.V. Zement-Prüfung der Leistungsfähigkeit hinsichtlich des Sulfatwiderstands-Bericht zum Stand der Technik. In DIN-Fachbericht CEN/TR 15697; Beuth Verlag GmbH: Berlin, Germany, 2008.

5. Müllauer, W. Mechanismen des Sulfatangriffs auf Beton-Phasenneubildungen und Expansionsdrücke in Mörteln unter $\mathrm{Na}_{2} \mathrm{SO}_{4}$ Belastung. Ph.D. Thesis, Technische Universität München, München, Germany, 2013.

6. Glasser, F.P.; Marchand, J.; Samson, E. Durability of concrete-Degradation phenomena involving detrimental chemical reactions. Cem. Concr. Res. 2008, 38, 226-246. [CrossRef]

7. Kunther, W.; Lothenbach, B.; Scrivener, K.L. On the relevance of volume increase for the length changes of mortar bars in sulfate solutions. Cem. Concr. Res. 2013, 46, 23-29. [CrossRef] 
8. Lee, S.T.; Moon, H.Y.; Hooton, R.D.; Kim, J.P. Effect of solution concentrations and replacement levels of metakaolin on the resistance of mortars exposed to magnesium sulfate solutions. Cem. Concr. Res. 2005, 35, 1314-1323. [CrossRef]

9. Loser, R.; Leemann, A. An accelerated sulfate resistance test for concrete. Mater. Struct. 2016, 49, 3445-3457. [CrossRef]

10. Müllauer, W.; Beddoe, R.E.; Heinz, D. Sulfate attack expansion mechanisms. Cem. Concr. Res. 2013, 52, 208-215. [CrossRef]

11. Ogawa, S.; Nozaki, T.; Yamada, K.; Hirao, H.; Hooton, R.D. Improvement on sulfate resistance of blended cement with high alumina slag. Cem. Concr. Res. 2012, 42, 244-251. [CrossRef]

12. Rozière, E.; Loukili, A.; El Hachem, R.; Grondin, F. Durability of concrete exposed to leaching and external sulphate attacks. Cem. Concr. Res. 2009, 39, 1188-1198. [CrossRef]

13. Shi, Z.; Ferreiro, S.; Lothenbach, B.; Geiker, M.R.; Kunther, W.; Kaufmann, J.; Herfort, D.; Skibsted, J. Sulfate resistance of calcined clay-Limestone-Portland cements. Cem. Concr. Res. 2019, 116, 238-251. [CrossRef]

14. Suma, F.M.; Santhanam, M. Influence of Specimen Size on the Expansion of Portland Cement Mortars Immersed in Sodium Sulphate Solution. In External Sulphate Attack-Field Aspects and Lab Tests: RILEM Final Workshop of TC 251-SRT (Madrid-SPAIN, 2018); Menéndez, E., Baroghel-Bouny, V., Eds.; Springer: Cham, Switzerland, 2020; pp. 81-91. ISBN 978-3-030-20331-3.

15. Wu, K.; Kang, W.; Xu, L.; Sun, D.; Wang, F.; de Schutter, G. Damage evolution of blended cement concrete under sodium sulfate attack in relation to ITZ volume content. Constr. Build. Mater. 2018, 190, 452-465. [CrossRef]

16. Zhongya, Z.; Xiaoguang, J.; Wei, L. Long-term behaviors of concrete under low-concentration sulfate attack subjected to natural variation of environmental climate conditions. Cem. Concr. Res. 2019, 116, 217-230. [CrossRef]

17. Bassuoni, M.T.; Nehdi, M.L. Durability of self-consolidating concrete to sulfate attack under combined cyclic environments and flexural loading. Cem. Concr. Res. 2009, 39, 206-226. [CrossRef]

18. Khayat, K.H.; Tagnit-Hamou, A.; Petrov, N. Performance of concrete wharves constructed between 1901 and 1928 at the Port of Montréal. Cem. Concr. Res. 2005, 35, 226-232. [CrossRef]

19. Yang, D.; Luo, J. The damage of concrete under flexural loading and salt solution. Constr. Build. Mater. 2012, 36, 129-134. [CrossRef]

20. Zhu, J.; Cao, Y.; Chen, J. Study on the evolution of dynamic mechanics properties of cement mortar under sulfate attack. Constr. Build. Mater. 2013, 43, 286-292. [CrossRef]

21. Biricik, H.; Aköz, F.; Türker, F.; Berktay, I. Resistance to magnesium sulfate and sodium sulfate attack of mortars containing wheat straw ash. Cem. Concr. Res. 2000, 30, 1189-1197. [CrossRef]

22. Guerrero, A.; Goñi, S.; Macías, A. Durability of new fly ash-belite cement mortars in sulfated and chloride medium. Cem. Concr. Res. 2000, 30. [CrossRef]

23. Guo, Z.; Wang, Y.; Hou, P.; Shao, Y.; Zuo, X.; Li, Q.; Xie, N.; Cheng, X. Comparison study on the sulfate attack resistivity of cement-based materials modified with nanoSiO 2 and conventional SCMs: Mechanical strength and volume stability. Constr. Build. Mater. 2019, 211, 556-570. [CrossRef]

24. Irassar, E.F.; Gonzalez, M.; Rahhal, V. Sulphate resistance of type V cements with limestone filler and natural pozzolana. Cem. Concr. Comp. 2000, 22, 361-368. [CrossRef]

25. Zhang, M.; Jiang, M.; Chen, J. Variation of flexural strength of cement mortar attacked by sulfate ions. Eng. Fract. Mech. 2008, 75, 4948-4957. [CrossRef]

26. Boyd, A.J.; Mindess, S. The use of tension testing to investigate the effect of W/C ratio and cement type on the resistance of concrete to sulfate attack. Cem. Concr. Res. 2004, 34, 373-377. [CrossRef]

27. Mulenga, D.M.; Stark, J.; Nobst, P. Thaumasite formation in concrete and mortars containing fly ash. Cem. Concr. Comp. 2003, 25, 907-912. [CrossRef]

28. Yan, C.; Yang, D.; Liu, S.; Zhang, J.; Hu, Z. Splitting Tensile Strength of Concrete Corroded by Saline Soil. ACI Mater. J. 2020, 117, 15-23. [CrossRef]

29. Matschei, T.; Glasser, F.P. Thermal stability of thaumasite. Mater. Struct. 2015, 48, 2277-2289. [CrossRef]

30. Haufe, J.; Vollpracht, A. Tensile strength of concrete exposed to sulfate attack. Cem. Concr. Res. 2019, 116, 81-88. [CrossRef]

31. Funk, J.E.; Dinger, D.R. Predictive Process Control of Crowded Particulate Suspensions; Springer: Boston, MA, USA, 1994; ISBN 978-0-7923-9409-9.

32. Westphal, T. Quantitative Rietveld-Analyse von amorphen Materialien. Ph.D. Thesis, Martin-Luther-Universität Halle-Wittenberg, Halle, Germany, 2007.

33. FIB. Fib Model Code for Concrete Structures 2010; Ernst \& Sohn: Berlin, Germany, 2013; ISBN 9783433604083.

34. Vollpracht, A.; Soutsos, M.; Kanavaris, F. Strength development of GGBS and fly ash concretes and applicability of fib model code's maturity function-A critical review. Constr. Build. Mater. 2018, 162, 830-846. [CrossRef]

35. Matschei, T.; Glasser, F.P. Temperature dependence, 0 to $40^{\circ} \mathrm{C}$, of the mineralogy of Portland cement paste in the presence of calcium carbonate. Cem. Concr. Res. 2010, 40, 763-777. [CrossRef]

36. Bellmann, F.; Möser, B.; Stark, J. Influence of sulfate solution concentration on the formation of gypsum in sulfate resistance test specimen. Cem. Concr. Res. 2006, 36, 358-363. [CrossRef]

37. Gollop, R.S.; Taylor, H.F.W. Microstructural and microanalytical studies of sulfate attack. V. Comparison of different slag blends. Cem. Concr. Res. 1996, 26, 1029-1044. [CrossRef] 